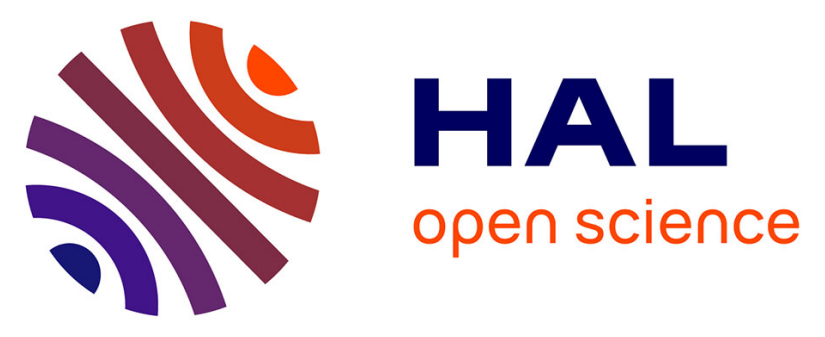

\title{
Structural control of weathering processes within exhumed granitoids: Compartmentalisation of geophysical properties by faults and fractures
}

\author{
J. Place, Yves Géraud, M. Diraison, G. Herquel, J.-B. Edel, M. Bano, E. Le \\ Garzic, B. Walter
}

\section{To cite this version:}

J. Place, Yves Géraud, M. Diraison, G. Herquel, J.-B. Edel, et al.. Structural control of weathering processes within exhumed granitoids: Compartmentalisation of geophysical properties by faults and fractures. Journal of Structural Geology, 2016, 84, pp.102-119. 10.1016/j.jsg.2015.11.011 . hal02457301

\section{HAL Id: hal-02457301 \\ https://hal.univ-lorraine.fr/hal-02457301}

Submitted on 18 Oct 2020

HAL is a multi-disciplinary open access archive for the deposit and dissemination of scientific research documents, whether they are published or not. The documents may come from teaching and research institutions in France or abroad, or from public or private research centers.
L'archive ouverte pluridisciplinaire HAL, est destinée au dépôt et à la diffusion de documents scientifiques de niveau recherche, publiés ou non, émanant des établissements d'enseignement et de recherche français ou étrangers, des laboratoires publics ou privés.

\section{(1) (1) $\$$}

Distributed under a Creative Commons Attribution - NonCommercial - NoDerivatives| 4.0 


\title{
Structural control of weathering processes within exhumed granitoids: Compartmentalisation of geophysical properties by faults and fractures
}

\author{
J. Place ${ }^{a, b}{ }^{b}{ }^{*}$, Y. Geraud $^{c}$, M. Diraison ${ }^{b}$, G. Herquel $^{b}$, J.-B. Edel ${ }^{b}$, M. Bano ${ }^{b}$, E. Le Garzic ${ }^{d}$, B. Walter ${ }^{c}$ \\ a University of Liverpool, Herdman Building, Liverpool L69 3GP, United Kingdom ${ }^{\mathrm{b}}$ Institut de Physique du Globe de Strasbourg, IPGS - UMR 7516 - CNRS, Universit!e de Strasbourg/EOST, 1 rue Blessig, \\ 67084 Strasbourg cedex, France ' Universit!e de Lorraine, Ecole Nationale Sup!erieure de G!eologie, UMR 7359-G!eoRessources, 2 rue du Doyen Marcel Roubault, TSA 70605, 54518 Vandoeuvre- \\ I"es-Nancy cedex, France \\ d ICTJA-CSIC Institute of Earth Sciences Jaume Almera, Lluis Sol!e i Sabarís s/n, 08028 Barcelona, Spain
}

abstract

In the latter stages of exhumation processes, rocks undergo weathering. Weathering halos have been described in the vicinity of structures such as faults, veins or dykes, with a lateral size gradually narrowing with depth, symmetrically around the structures.

In this paper, we describe the geophysical characterisation of such alteration patterns on two granitoid outcrops of the Catalan Coastal Ranges (Spain), each of which is affected by one major fault, as well as minor faults and fractures. Seismic, electric and ground penetrating radar surveys were carried out to map the spatial distribution of P-wave velocity, electrical resistivity and to identify reflectors of electromagnetic waves. The analysis of this multi-method and complementary dataset revealed that, at shallow depth, geophysical properties of the materials are compartmentalised and asymmetric with respect to major and subsidiary faults affecting the rock mass. This compartmentalisation and asymmetry both tend to attenuate with depth, whereas the effect of weathering is more symmetric with respect to the major structure of the outcrops. We interpret such compartmentalisation as resulting from the role of hydraulic and mechanical boundaries played by subsidiary faults, which tend to govern both the chemical and physical alterations involved in weathering. Thus, the smoothly narrowing halo model is not always accurate, as weathering halos can be strongly asymmetrical and present highly irregular contours delimiting sharp contrasts of geophysical properties.

These results should be considered when investigating and modelling fluid storage and transfer in top crystalline rock settings for groundwater applications, hydrocarbon or geothermal reservoirs, as well as mineral deposits.

1. Introduction

As a result of hypogene processes (occurring at great depth), fault zones acquire physical and chemical properties that differ from the rock mass they affect. Exhumation of crystalline basement rocks leads to exposure of the granitoid to erosional agents. The later overprint of supergene alteration within and near fault zones. Fault zones may act as conduits, barriers, or a combined conduit-barrier system, depending on their architecture and the fault rock materials that have developed (Caine et al., 1996; Bense et al., 2013). In situ hydrological testing has shown that fault and fracture networks represent preferential flow paths and storage capacities in crystalline rocks (e.g. Brace,1984; Caine and Tomusiak, 2003; Aquilina et al., 2004; Roques et al., 2014). However, in some instances, clay-like materials concentrate into fault cores as a result of the alteration of primary minerals. This has a dramatic impact on the hydraulic behaviour of fault zones, as the fault core acts as a barrier to transverse flow. In contrast, the damage zones, of improved permeability in comparison with fresh rocks and the fault core, may concentrate and channel the flow along the direction of the fault zone (Caine et al., 1996; Kirkpatrick et al., 2008). This results in compartmentalisation of fluid storage and transfer capacities of the rock mass (Bense et al., 2013).

Weathering processes dramatically change the chemical and physical properties of basement rocks: matrix porosity and permeability exhibit much broader ranges than those of fresh rocks, and new fractures may develop. The formation of new cracks, or cracks formed prior to weathering, contribute to fluid circulation (Biscaldi, 1968; Chilton and Smith-Carington, 1984; Acworth, 1987; Owen et al., 2007; Neves and Morales, 2007; Le Borgne et al., 2006; Durand et al., 2006; Røyne et al., 2008). Subsequent weathering of micas and feldspar (Folk and Patton, 1982; Banfield and Eggleton, 1988) results in an increase of both porosity and permeability. Alteration products tend to precipitate locally due to the tortuosity of the porous network, which in turn tends to increase (especially in the case of ferric minerals, Fletcher et al., 2006) or decrease the permeability (Bisdom et al., 1982; Nishimoto et al., 2010).

However, the way weathering overprints features that formed at greater depth (fractures, veins, hydrothermal alteration etc.) is not very well-understood. In some instances, faults can produce less weathered rock, because cements produced by fluid flow through the fault materials when the fault was at depth resulted in more competent formations than the protolith (Faulkner et al., 2011; Smith et al., 2013; Soden et al., 2014). In other cases, fault zones or fractured corridors can be preferentially weathered to such an extent that they may present favourable reservoir properties such as HRA e Hard Rock Aquifers (Gustafson and Krasn! ý, 1994; Taylor and Howard, 2000; Wyns et al., 2004; Dewandel et al., 2006; Lachassagne et al., 2011; Chandra et al., 2013; Leray et al., 2013; Guiheneuf et al., 2014 ! ). Not only primary lithologies, but also the fracture pattern (Hill, 1996), as well as regional factors such as the tectonic uplift (Riebe et al., 2001) or the regional stress field (Owen et al., 2007) are involved in controlling weathering processes. Weathered formations developed in the vicinity of structures such as faults, dykes and veins, affect the storage and transfer properties of the system and may make it more complex than if control was by unweathered structures (e.g. Roques et al., 2014).

The weathering halo is typically represented symmetrically around the main structure it is related to and smoothly narrows with depth (Dewandel et al., 2006; Durand et al., 2006; Chandra et al., 2010; Dewandel et al., 2011). In some cases, exhumed basement rocks may subside and subsequently lie underneath a thick 
sedimentary material. Fluids are still able to circulate and be stored within the porosity related to paleo-weathering. Significant hydrocarbon resources have been identified within many such naturally fractured basement rock reservoirs (Aydin, 2000; Petford and McCaffrey, 2003; Schutter, 2003; Sicar, 2004; Luthi, 2005; Dontsov and Lukin, 2006; Cuong and Warren, 2009; Gutmanis, 2009; Gutmanis et al., 2012). Examples of productive alteration halos have been reported with a vertical component of up to $2 \mathrm{~km}$ and a horizontal width up to of $800 \mathrm{~m}$ (Ngoc, 2007). Paleo-weathered basement rocks can also represent favourable conditions for developing geothermal exchangers (Manning et al., 2007; Younger and Manning, 2010) or for mineral deposition (Boiron et al., 2010). Aside from exhumation itself (Soden et al., 2014), weathering processes may include the generation of new fractures. The occurrence of fractures oriented sub-parallel to the erosion surface has been reported in several cases (Wyns et al., 2004; Dewandel et al., 2006; Courtois et al., 2010). Their formation is interpreted as resulting from a volume increase of some mineral phases when these are altered (primarily biotite, see Banfield and Eggleton,1988; Folk and Patton,1982; Tieh et al.,1980; Mc Farlane,1992; Hill,1996; Wyns et al., 2003; Rodbell et al., 2012), with cracks forming orthogonally to the minimum stress, that is to say forming subparallel to the erosion surface. Lachassagne et al. (2011) have formalised a qualitative stress analysis of this problem. However, to our knowledge, no numerical approach has validated this concept. Fractures of other orientation can also occur, developing hierarchically with a wide variety of orientation, or forming spheroidal patterns (Fletcher et al., 2006; Røyne et al., 2008; Jamtveit et al., 2009; Jamtveit et al., 2011).

An accurate characterisation of basement rocks near to the surface is required for a better understanding of properties of shallow aquifers or deep reservoirs, including fluid circulation and storage (e.g. Acworth,1987; Neuman, 2005; Roques et al., 2014). For example, the depth of present day and paleo-weathering fronts have been estimated as a few metres (Virgili et al., 1974), several tens of metres (Radzevicius and Pavlis, 1999; Dewandel et al., 2006), hectometres (Genter and Traineau, 1996; Olesen et al., 2007), or up to a kilometre (Luthi, 2005). The factors governing deepening, and therefore lateral and depth extents of weathering in the vicinity of major structures, still require investigation. Even though geophysical surveys have been able to characterise weathering fronts in poorly faulted formations (Lee and de Freitas, 1990; Radzevicius and Pavlis, 1999; Carvalho et al., 2000; Fonseca et al., 2006; Carvalho et al., 2010; Olona et al., 2010), to our knowledge only a few such surveys have been focused on the deepening of weathering fronts in the vicinity of structures such as faults (Wyns et al., 2004; Dewandel et al., 2006; Chandra et al., 2010, and references therein). In this paper, we focus on two faults outcropping in weathered granitoids of the Catalan Coastal Ranges (Spain). These systems are assumed to be surface analogues of aquifers (such as some types of HRA), deep reservoirs (e.g. geothermal, hydrocarbons) or mineral deposits. The first aim of this study is to investigate the geophysical properties of fault zone materials, using geophysical methods. We describe the geological setting of the case studies as well as the methods used. The new and comprehensive geophysical data obtained in the field reflect the spatial distribution of weathering severity, which allows us to discuss and better identify the factors controlling weathering processes.

\section{Geological setting}

\subsection{General setting and site selection}

In the following sections, the term "protolith" refers to fresh rock, free from fracturing or alteration, somehow related to the fault zone; this definition is irrespective of any weathering. Similarly, "damage zone" and "fault core" are defined as the volume of material affected by a moderate to high degree of fracturing or alteration, somehow related to tectonic or hydrothermal processes, especially when at depth. The term "block" refers to a structural compartment bounded by faults.

The granitic Cadiretes Massif within the Catalan Coastal Ranges was chosen to carry out our field investigations (Fig. 1). This choice was motivated by the fact that the tectonic and exhumation history of the crystalline basement rocks are fairly well-constrained in this area. The magmatism in the Calalan Coastal Ranges started around $324 \mathrm{Ma}$ for the Guilleries diorites (UePb zircon ages; Martínez et al., 2008). Most of the granites emplaced at $291 \mathrm{e} 285 \mathrm{Ma}$ for gabbroic rocks and granitoids of the Montnegre massif $\left({ }^{40} \mathrm{Ar} /{ }^{39} \mathrm{Ar}\right.$ ages; Sole! et al., 2002, and see Institut Geologic de Catalunya, Base Geol" ogica" $1: 50000$, May 2007). In the Late Permian, the massif was intruded by multiple dykes of various chemical composition striking EeW to ESEeWNW (Martínez-Poza et al., 2014). The Catalan Coastal Ranges have undergone a multi-phase tectonic history, in which the first major event was relaxing of the Variscan orogen, coeval with the formation of basins in the

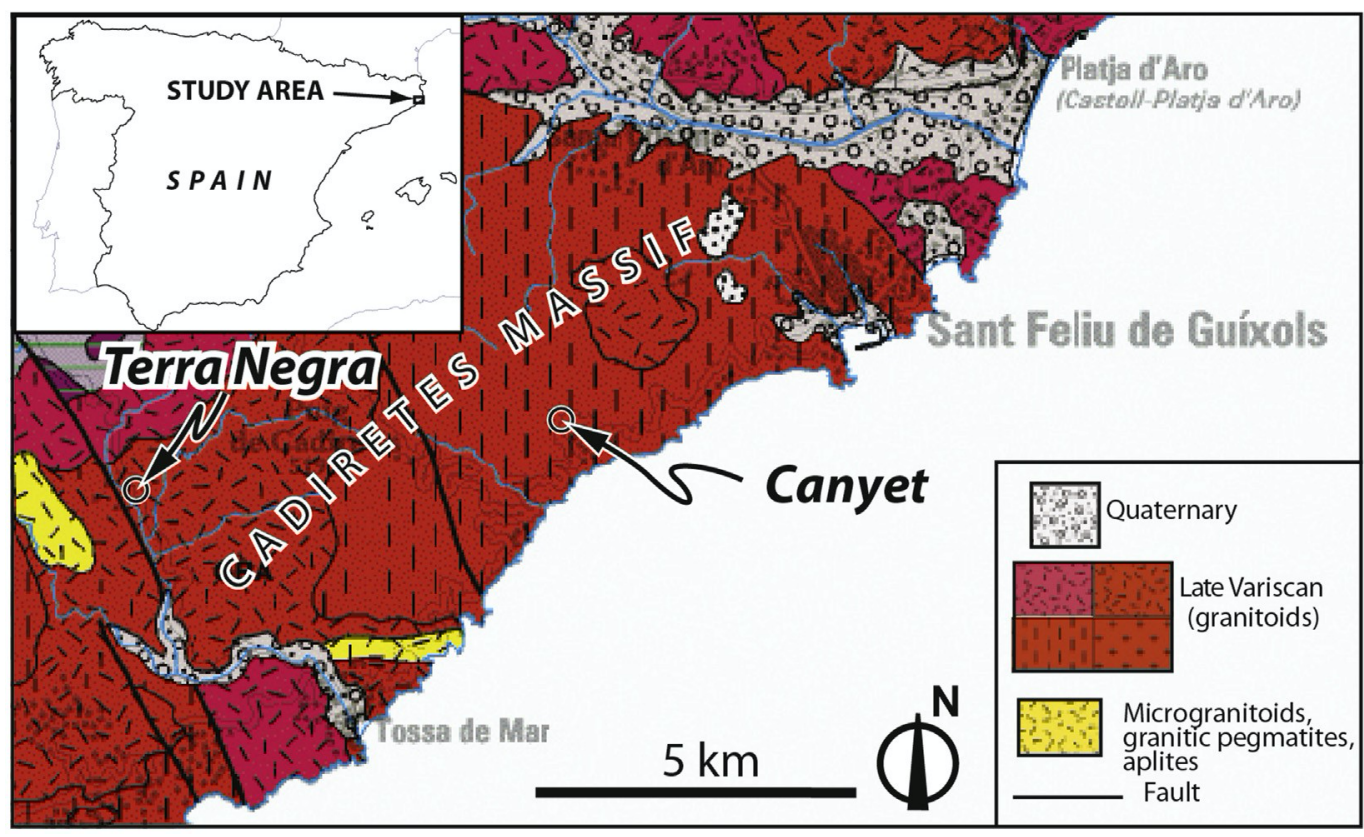

Fig. 1. Location of the Canyet and Terra Negra sites within the Cadiretes Massif, Catalan Coastal Ranges, NE Spain (modified after Mapa geologic de Catalunya 1:250,000)." 
late Permian and Triassic eras (Arthaud and Matte, 1975; Bixel, 1987; Arche et al., 2007). The geodynamic evolution of the Catalan Coastal Ranges from Late Carboniferous to Early Triassic times (i.e. during the successive magmatic pulses) was recently unravelled by Edel et al. (2015). Continued regional subsidence affected the area until the Hettangian, which is interpreted as being related to the western termination of the Tethys domain (Salas and Casas, 1993; Doblas et al., 1994). No major tectonic event seems to have affected the area during the Lower and Mid-Jurassic, until a significant extensional regime was established from the Upper Jurassic, first as a local response to the opening of the Northern Atlantic Ocean, followed by the opening of the Bay of Biscay at the end of the Upper Cretaceous (Stampfli et al., 2002; Verges et al., 2002!). The rifting separating the Iberian plate from the European plate then relaxed, and the Pyrenean domain entered a thermal subsidence at the end of the Cretaceous (Salas and Casas, 1993). The collision between the Iberian and European plates was initiated in the Palaeogene and this resulted in the formation of the Pyrenees (Salas and Casas, 1993; Verges! et al., 2002). This compressive event is thought to have affected the Catalan Coastal Ranges until the Oligocene, when the southern termination of the European Cenozoic Rift System propagated through the area (Ziegler, 1992; Tassone et al., 1994; Verges et al., 2002; Bourgeois! et al., 2007). Much of the present day topography, especially the prominence of the Catalan Coastal Ranges, derives from Neogene to Quaternary tectonics (Lewis et al., 2000) (Fig. 1). This indicates that the materials and structures occurring in upper positions within the tilted blocks are not likely to have undergone any paleoweathering (especially pre-Triassic) such as that described in other places preserved from erosion (Virgili et al., 1974). Only the current weathering is thought to have affected the rocks studied in this paper. The unique nature of weathering phases was a prerequisite to site selection, to facilitate the interpretation of results.

The site selection process then followed exposure and accessibility criteria. By exposure, we mean that a significant volume of rocks around the fault zones had to outcrop as a result of anthropogenic excavation, to expose fresh materials that would not have been accessible otherwise. Outcrops formed by road cuts were preferred, as these offer good slope stability, as well as excellent access conditions for geophysical measurements and sampling. Two sites, namely Canyet and Terra Negra, were finally chosen

(Fig. 1).

\subsection{Site description}

The two sites studied here consist of steep outcrops, decametric to pluri-decametric in height, offering excellent exposure of fault materials developed in coarse-grained leucogranites that are Permo-Carboniferous in age (Sole et al., 2002! , and see Institut Geologic de Catalunya, Base Geol" ogica 1:50000, May 2007) (" Figs. 2 and 3). The faults lie entirely within a single rock type, with no obvious faulted structure such as pegmatite or dyke to provide information about the displacement along the fault. The major fault cores studied at each of the two sites exhibit high clay content in sharp contact with damage zones or protolith (Figs. 2 and 3) and are significantly eroded due to leaching. Samples were collected and examined for thin section and clay content analysis (Figs. 2 and 3; see Appendix). They were taken at a few tens of centimetres in depth, so as to reach in situ materials not affected by erosion which had occurred since the outcrops were dug. Both sites are accessible for setting up geophysical instruments at the bottom of the cliff and on its top (Canyet; Fig. 2) or on a berm in the cliff (Terra Negra; Fig. 3 ). This allowed several seismic experiments to be carried out in transmission through the outcropping formations, which is relevant for interpreting geophysical results with respect to the 

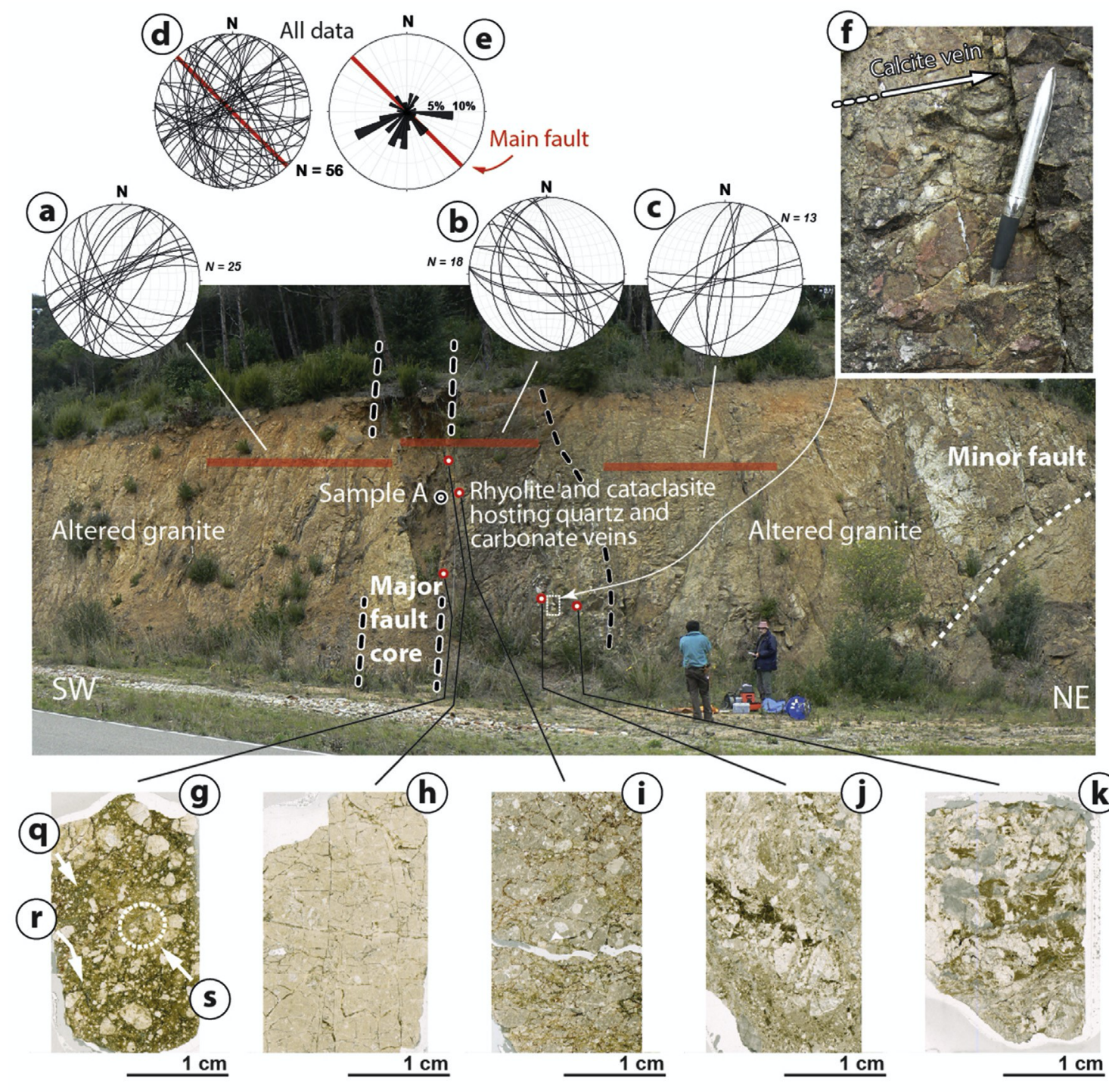

(c)
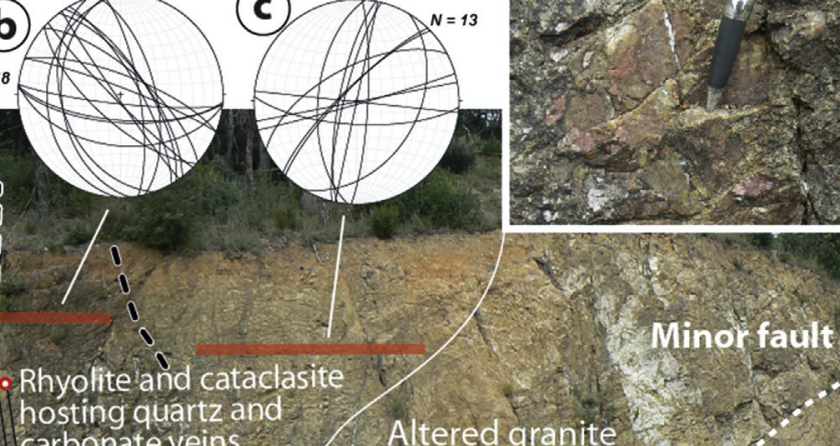

3

Minol fault hosting quartz and carbonate veins

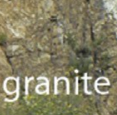



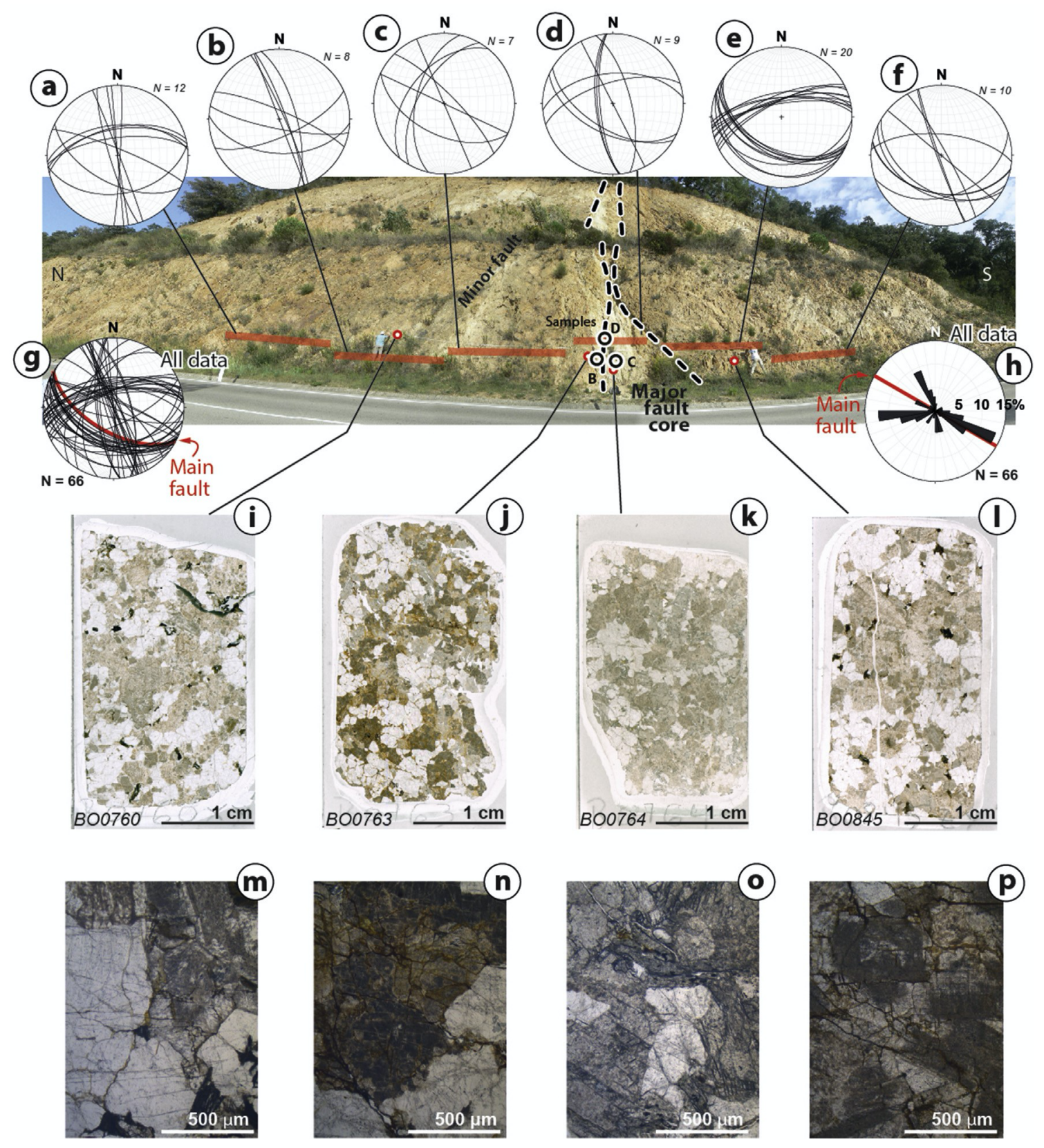

Fig. 3. Panoramic view of the Terra Negra site, with (aeh) fracture data (fractures showing an extent of at least $1 \mathrm{~m}$ ). iel: thin sections of selected samples as seen under natural light. mep: planepolarized light views under the microscope of samples iel, respectively. Samples B, C and D used for X-ray diffraction analysis (in Appendix) are located on the panoramic view.

ultramylonitic (Fig. 2q) or rich in iron oxides (Fig. 2r). Calcite cementation zones are also locally present, without strong evidence of structural control (Fig. 2s). Cataclastic texture is found in the fault core; other fault materials from the Canyet outcrop show larger grain size and a lesser quantity of matrix. Both K-feldspar and plagioclase are grey, associated with weathering and clay precipitation. Hardly strained rhyolitic material is found at the edge of the fault core (Fig. $2 \mathrm{~h}$ and $\mathrm{m}$ ). A set of micro-cracks delimit fragments with a size ranging between $0.5 \mathrm{~cm}$ and $50 \mathrm{~mm}$, with little or no relative displacement and no filling. Further away from the fault core, highly strained materials exhibit a proto-cataclastic texture, with fragment size ranging from $10 \mathrm{~mm}$ to millimetres (Fig. $2 \mathrm{i}$ and $\mathrm{n}$ ). The matrix fraction is low (about $20 \mathrm{e} 40 \%$ ) and the angular clasts consist mainly of rhyolite and granite. Some of the biggest clasts are affected by micro-cracks. Further north, cataclasites with a matrix occupying a smaller volume (about 10e20\%) than in the fault core are cross-cut by calcite veins (Fig $2 f, j$ and o). Calcite grains are found in these cataclasites, along with granitic and rhyolitic grains. At a greater distance from the fault core, the grain size of the cataclasite increases (Fig. $2 \mathrm{k}$ and $\mathrm{p}$ ), and contains twinned calcite and a poor matrix content. The weathering processes mainly affect feldspar and biotite in the granitic facies and are less pronounced in the rhyolitic facies even though the matrix elements are only altered in the high strain zone. Finally, a subsidiary south dipping fault affects the north eastern part of the outcrop. On the Terra Negra site, the outcrop striking N170!E exhibits one major and one minor fault oriented N120!E 60!SW and N160!E 90!, respectively (Fig. 3). Three fracture sets dominate the fracture network (Fig. $3 \mathrm{~g}$ and h): N080!E dipping steeply to the north, N120!E with a moderate dip to the south-west (and therefore subparallel to the major fault), and sub-vertical fractures striking N170!E. Each family occurs in almost all the fault blocks (Fig. 3 aef), but with various severity. 
Sample and thin section analysis indicates that micro-cracking and weathering both vary from the protolith towards the fault core. The protolith (Fig. $3 \mathrm{i}$ and $\mathrm{m}$ ) exhibits the lowest density of micro-cracks found in the outcrop. Feldspar and plagioclase are grey under the microscope, indicating some chemical alteration. This is more pronounced in the immediate vicinity of the cracks. Some of the cracks developed in the quartz have healed, but others, affecting all mineral phases, are still open. In the damage zone, material is densely cracked, especially the quartz grains, some of which exhibit fluid-bearing sutures (Fig. 31 and p). The grey colour of K-feldspar and plagioclase under optical microscopy indicates that they have localised clay precipitation and weathering. Biotites are slightly weathered and present iron oxides locally at their edges. Another sample from the damage zone (Fig. 3j and $n$ ), as well as the edge of the fault core (Fig. 3k and o), shows a dense network of micro-cracks affecting both quartz and K-feldspar grains, many of these micro-cracks being filled with iron oxides. Biotite grains are partly replaced with chlorite.

Neither outcrop presents a fissured horizon such as described in Wyns et al. (2004) (defined by an anomalous number of fractures sub-parallel to the erosion surface) as shown by the fracture diagrams and the panoramic views (Figs. 2 and 3). Regarding the major faults affecting the two outcrops, their approximate NWeSE strike suggests they might have accommodated the opening of Late Carboniferous to Permian basins in the context of late Variscan extensional tectonics (Arthaud and Matte, 1975; Bixel, 1987). They may also have been part of the Catalan Transfer Zone, which accommodated a right lateral motion during the opening of the Gulf of Lion and Provence Basin, which was particularly intensive in the Burdigalian (Seranne, 1999; Mauffret et al., 2001! ). Following this extensional regime, thermal subsidence occurred in the MidMiocene; a few NWeSE striking faults have shown evidence of extensional activity since then (Bartrina et al., 1992; Tassone et al., 1994). Kinematic criteria on the outcrops are unfortunately too scarce to identify a possible record of this tectonic history, but the observed structures at the outcrop scale are thought to be the cumulative result of these deformation phases. As the fault core thicknesses range from around 30 to $80 \mathrm{~cm}$, the cumulated displacement can be tentatively estimated as between a few metres and a few hundred metres after the data given in Childs et al. (2009) and Fossen (2010).

\section{Geophysical methods}

Three geophysical methods were used to benefit from their complementarity in terms of penetration, resolution and sensitivity to various physical properties. The reduction of $\mathrm{P}$ wave velocity (measured using first-break seismic tomography) and resistivity (investigated using Electrical Resistivity Tomography ERT) in crystalline rocks are often related to chemical alteration and physical damage such as fracturing and faulting. This is illustrated by experiments carried out at depth through boreholes or galleries far from any weathering (Jamtlid et al., 1984; $€$ Hayles et al., 1999; Jeanne et al., 2012). Other field studies demonstrated the sensitivity of seismic methods to alteration fronts (Lee and de Freitas, 1990; Radzevicius and Pavlis, 1999).

Therefore, combining seismic and electric methods is appropriate to characterise weathering of fractured crystalline rocks. In addition, the occurrence of shallow and sub-horizontal structures is described in relation to weathering (see above) and radar methods have shown a strong potential in their detection, separately or in the form of swarms (Tillard, 1994). Radar surveying is therefore also relevant in the investigation of weathering processes, especially to complement seismic and electric tomography methods with low resolutions.

The access condition to the outcrops allowed an extensive use of these methods, especially seismic surveys with the receivers and sources positioned in original arrays to make use of the topography; in this way, our field approach fell into the category of "behind-the-cliff" geophysics, aiming to provide new data for studying fault zone materials in weathered granitic formations.

\subsection{Seismic tomography}

Seismic data were collected using a 48 channel Geometrics Strataview connected to 48 vertical geophones, with a nominal frequency of $14 \mathrm{~Hz}$. A sledge hammer hitting a steel plate was used to generate the elastic waves. Sources and sensors were aligned along straight lines. In some cases topography was utilised to spread them in original arrays so that fault blocks could be thoroughly sampled by various ray paths (Figs. 4 and 7). Signals were recorded in SEG2 format at 5 " $10^{\sharp 4} \mathrm{~s}$ sampling rate for $0.512 \mathrm{~s}$. Up to ten records were stacked at each source position to enhance the signal to noise ratio.

The first arrival picking and travel time inversions were based on the Simultaneous Iterative Reconstruction Technique (SIRT) (e.g. Hayles et al., 1999; Zou and $\mathrm{Wu}, 2001)$. These were performed with Reflexw developed by Sandmayer Scientific Software. Both the geometry of acquisition and the travel times were used to produce images of the velocity field. The 2D inversion module was used to process data collected along lines or Reverse Vertical Seismic Profiles, whereas data acquired with complex geometry were processed using the 3D module. A visualisation tool has been implemented to view the results obtained in 3D along a plane of given orientation.

\subsection{Electrical Resistivity Tomography (ERT)}

Resistivity of the subsurface was measured using an automatic SYSCAL Junior Switch 48 resistivity metre from Iris Instruments, connected to 48 electrodes operated according to a Wenner array (Wenner, 1915). Electrodes were planted at 1 or $2 \mathrm{~m}$ spacing along $47 \mathrm{~m}$ or $94 \mathrm{~m}$ long profiles, respectively, orthogonally to the main faults (Figs. 4 and 7). 2D resistivity sections were obtained after processing the data with the Res2dinv inversion software developed by Geotomo Software. The interpretation was restricted to shallow levels, where the uncertainty is the lowest (see dotted lines on Figs. 5 and 8). To check the validity of the 2D hypothesis, which is the striking condition for applying the Res2DInv inversion, close profiles were set up parallel to each other. 


\subsection{Ground penetrating radar (GPR) profiling}

We performed 2D GPR measurements along the outcrops with shielded 100 and $250 \mathrm{MHz}$ antennae, respectively, and used a RAMAC GPR acquisition system made by Malå Geosciences. For all profiles, the acquisition mode was a constant offset, which allowed reflections of electromagnetic waves occurring off shallow dipping structures to be preferentially detected. The processing of all GPR profiles was performed with Matlab scripts written in our laboratories (Dujardin and Bano, 2013). This is a common flow procedure involving a constant shift to adjust the zero time, a DC filter to remove the low frequencies, a flat reflection filter to remove continuous flat reflection noise (ringing related to the shielding), a time varying gainer function and finally a band-pass filter. The band-pass filters were of $40 \mathrm{e} 300$
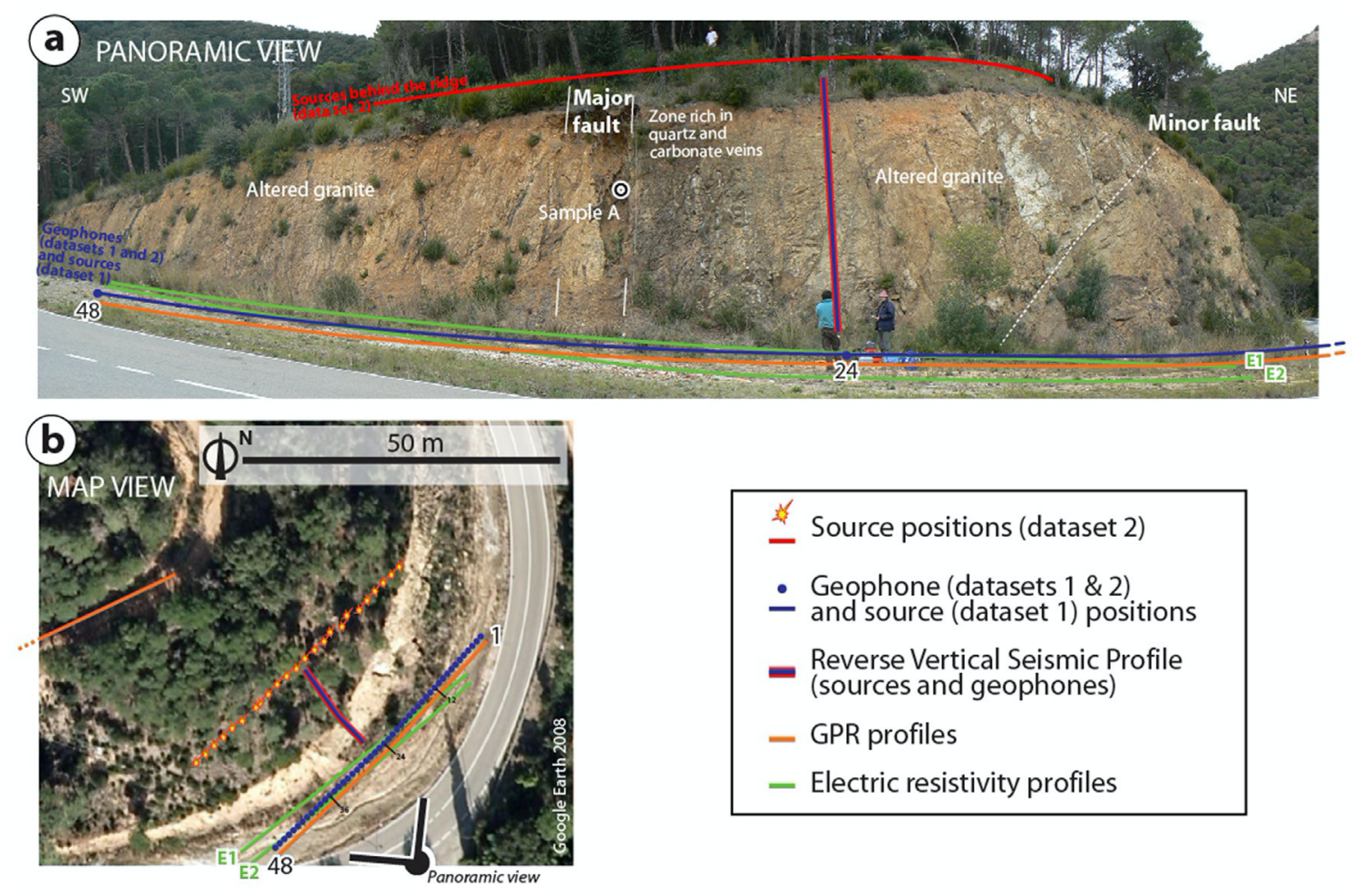

Nource positions (dataset 2)

- Geophone (datasets 1 \& 2).

- and source (dataset 1) positions

- Reverse Vertical Seismic Profile

(sources and geophones)

- GPR profiles

- Electric resistivity profiles

Fig. 4. Panoramic (a) and map (b) views of the Canyet site showing the position of the geophysical equipment.

$\mathrm{MHz}$ and $50 \mathrm{e} 600 \mathrm{MHz}$ for the 100 and $250 \mathrm{MHz}$ antennae, respectively.

The position of profiles was measured with centimetric accuracy using a theodolite. This allowed data processing involving ray propagation and electric current lines to be accurately applied and helped with comparing various results obtained after processing.

4. Results at the Canyet outcrop

4.1. Seismic

4.1.1. Acquisition

Two seismic profiles across the major fault zone have been acquired (Fig. 4). One was conducted at the bottom of the cliff, with a geophone spacing of $2 \mathrm{~m}$ and a source spacing of $4 \mathrm{~m}$ (Dataset 1), whereas a second profile was acquired with the sources positioned on top of the cliff at a distance from the ridge, keeping the geophones at the same place at the bottom of the cliff (Dataset 2). A third acquisition was carried out parallel to the fault zone, with the geophones planted in the soil on top of the cliff and the sources along the same line (Fig. 4); shots were also carried out in the cliff using mountaineering techniques. As the impact of the hammer on the rock was strong enough to trigger the record, the use of the steel plate was not necessary. Such geometry allows investigation of the velocity within one fault block according to the so-called Reverse Vertical Seismic Profile technique (Zou and Wu, 2001). RVSP data and Dataset 1 were processed using a 2D algorithm, assuming that the propagation occurred within vertical planes, whereas Dataset 2 was processed using a 3D transmission tomography algorithm (similar to crosshole seismic techniques).

4.1.2. Results

Due to a limited ray coverage at the two ends of the 1D velocity profile (Dataset 1), results of the tomography should not be interpreted with confidence at these locations (the last $8 \mathrm{~m}$ on either end of the profile, Fig. 5b). A low-velocity anomaly was resolved to the south west of the major fault zone (geophones 33 to $42, V_{p} z 1000$ m.s! ${ }^{1}$ ). Moderate to high-velocity values were found between geophones 33 to $18\left(V_{p} z 1700\right.$ m.s! $\left.{ }^{1}\right)$, suggesting an asymmetry of the velocity field about the fault zone. Even higher values were measured from the geophone 15 up to the north eastern end of the profile $\left(V_{p} z 2000 \mathrm{~m} . \mathrm{s}^{1}\right)$. Although a slight lowvelocity anomaly was detected at the location of a minor fault (geophones 15 to 18), the three fault blocks seen from the outcrop were characterised by various P wave velocities that were significantly smaller than that commonly known for fresh granite (ca. 5800 m.s! ${ }^{1}$, see for example Salisbury et al. (2003) and Place et al. 
(2011)).

Basic analyses of true amplitude in shot-gathers exhibited a significant loss of energy when crossing the fault (Fig. 5c), in agreement with the high contrast in velocity identified at this location. These observations confirm that the fault was the major feature affecting seismic wave propagation at the bottom of the cliff.

Results of 3D tomography (Dataset 2) exhibited a strong asymmetry (Fig. 5a). The P wave velocity distribution in the SW block was homogeneous with a mean velocity of about $830 \mathrm{~m} . !^{1}{ }^{1}$, which was about $42 \%$ less than that of the NE block (1430 m.s! $)^{1}$ ).

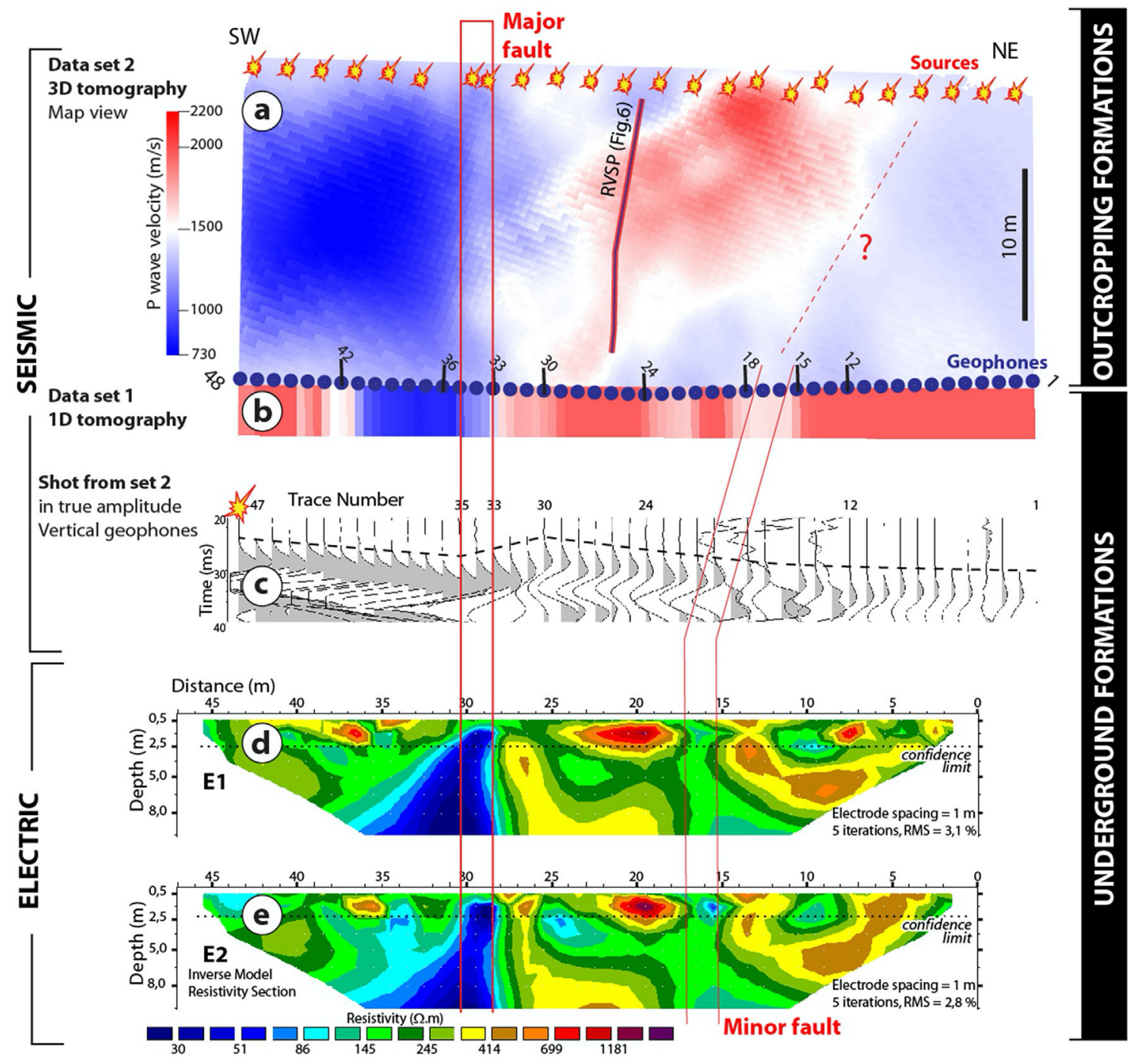

Fig. 5. Results of geophysical surveys carried out at the Canyet outcrop. In the outcropping formations, the P wave velocity field is strongly asymmetric with respect to the major fault, whereas both $P$ wave velocity and electric resistivity exhibit significantly more symmetrical distribution at depth.

Therefore the fault zone was not a low-velocity zone embedded within a high-velocity protolith, but appeared to be a boundary between two zones of contrasted velocity, with high-velocity in the NE part and low-velocity in the SW part. It is worth noting that sources located at the NE end of the profile were close to the ridge (Fig. 4b). This required the rays to bend in order to reach the geophones, which means that their actual length was greater than those considered in the algorithm. Consequently, the velocities in this part of the profile were significantly underestimated, preventing any robust interpretation. Comparing the fracture data with the seismic velocity field showed some degree of correlation, with the largest number of fractures occurring in the southwestern block of low velocity (Figs. 2 and 5).

The velocity field exhibited spatial variations in the two tomographic pictures within the block located between the two faults (geophones 33 to 18 , Fig. 5 a and $b$, with velocity values ranging between 1300 and $\left.2200 \mathrm{~m} . \mathrm{s}^{1}{ }^{1}\right)$. We speculate that such seismic features could be related to the indistinct variation in the distribution of carbonate and quartz veins identified from the outcrop (Fig. 2f), which are high-velocity materials (6050 and 6530 m.s! for quartz and calcite, respectively, after Carmichael (1989)) occurring within the low-velocity host rock.

Inversion of RVSP data produced the best result (most realistic), when starting from initial velocity models with a vertical velocity gradient rather than from homogeneous models (Fig. 6a). After inversion, very low velocities (200e1500 m.s! ${ }^{1}$ ) were found within the top $3 \mathrm{~m}$ of the volume investigated (Fig. 6b). Field observations showed that the top of the granite was very close to the surface. Buried under a maximum of a few tens of centimetres of soil, the rock mass exhibited heavy weathering in the form of regolith saprolite in the upper level. P wave velocity increased with depth from about 3200 to $3800 \mathrm{~m} . \mathrm{s}^{1}{ }^{1}$ at ca. $8 \mathrm{~m}$ below ground level. As the ray coverage decreases with depth, the second-order spatial variations observed at this level should be considered more as geophysical uncertainties than as geological features. Relatively high velocities of about $2500 \mathrm{~m}$.s! ${ }^{1}$ were observed $1.5 \mathrm{~m}$ behind the cliff wall (Fig. $6 \mathrm{~b}$ ). The velocity gradient was therefore about $1000 \mathrm{s!} !^{1}$ orthogonally to the wall, whereas significantly lower values ranging between 360 and $435 \mathrm{~s} !^{1}$ were found orthogonally to the top surface of the rock mass (Fig. 6b). The near-horizontal gradient could be interpreted as a consequence of the damage 

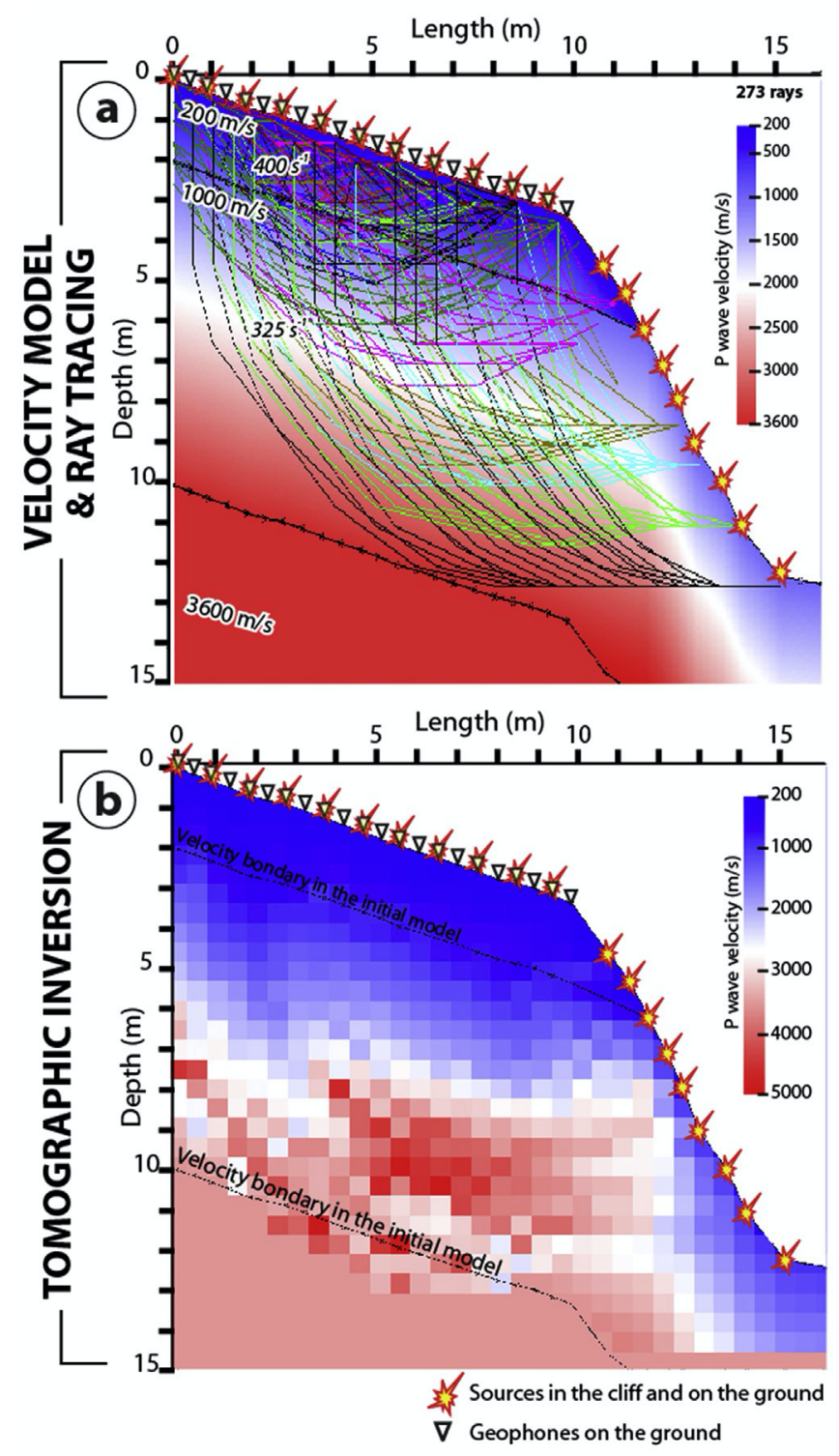

Fig. 6. Initial velocity model (a) and results (b) of Reverse Vertical Seismic Profiling carried out within the NE fault block of the Canyet site. The near-vertical P wave velocity gradient is related to weathering, whereas the higher magnitude near-horizontal gradient behind the cliff is interpreted to be related to the anthropogenic damage.

related to the excavation alongside local stress field changes due to the presence of a free surface (by analogy to Excavation Damaged Zones (EDZ), see Alheid et al. (1998)). The near-vertical gradient could be related to natural weathering processes as documented by Radzevicius and Pavlis (1999). It is worth noting that the extent of such gradients (at least $10 \mathrm{~m}$ in depth, Fig. 6b) can explain the general increase in the apparent velocity with the distance from the source to the geophone observed in all seismic data sets recorded at this site.

\subsection{Electrical resistivity}

Two profiles were acquired about $2.5 \mathrm{~m}$ apart, orthogonally to the major fault zone (Fig. 4). After inversion, the resistivity sections showed a prominent lowresistivity anomaly at the site of the major fault zone (offsets between 28 and $30 \mathrm{~m}$, Fig. $5 \mathrm{~d}$ and e). We related this to the high clay content of the fault zone, which supposedly trapped water more effectively than did the host rock. The minor fault was also characterised by a drop in the resistivity at offsets of $15 \mathrm{e} 17 \mathrm{~m}$, but this was much less pronounced than in the previous case. The three fault blocks exhibited a similar order of magnitude of resistivity, with the central block showing secondorder variations possibly related to the carbonate and quartz veins (Fig. 2). This contrasted with the P wave velocity partitioning described earlier in the outcropping formations. 
GPR profiling was carried out at the bottom of the cliff, as well as on a path on the clifftop, in a direction approximately orthogonal to that of the fault zone (Fig. 4). No particular reflection was detected with either antenna. This suggested that the alteration front, such as that evidenced in RVSP, contained no shallowdipping interfaces, exhibiting sharp enough contrasts in electric permittivity and conductivity to significantly reflect electromagnetic waves at the frequencies used. No other reflectors, such as shallow dipping exfoliation structures, were detected from GPR data in the rock mass. This was supported by outcrop analysis that did not reveal any particular sub-horizontal fracture pattern (Fig. $2 \mathrm{~d}$ and e).

5. Results at the Terra Negra outcrop

5.1. Seismic

5.1.1. Acquisition

The position of the equipment is given in Fig. 7 on both a map and panoramic views, as well as in sketches of the outcrop for each dataset. Seismic data were acquired at the bottom of the cliff, with a geophone spacing of $2 \mathrm{~m}$ and a source spacing of $4 \mathrm{~m}$ (Dataset 1; Fig. 7c). This set-up allowed all of the main structural compartments seen at the outcrop to be sampled. Another survey was carried out with the same geophone locations, but the sources were positioned on the cliff berm (Dataset 2; Fig. 7d). In this way, direct transmission through the outcropping rock mass could be achieved. A similar experiment focused on the fault zone at higher resolution, by using 24 geophones with a spacing of only $1 \mathrm{~m}$, and fewer sources above (Dataset 3 ; Fig. 7e). In the last survey, the equipment was set-up vertically in the cliff, to focus on the fault zone itself, taking advantage of the soft material of the minor fault to plant the geophones and hit the wall directly with the hammer (Dataset 4; Fig. 7f). Datasets 2, 3 and 4 allowed 3D transmission tomography algorithms to be applied.

5.1.2. Results

The apparent velocity was observed to generally increase with the distance between the source and the geophone in all data sets, as noted at the Canyet site. This also reflected the presence of a velocity gradient, with the velocity increasing with penetration into the rock mass, implying a curvature of the ray paths. From Dataset 2, the hanging wall of the major fault exhibited a low P wave velocity $\left(600 \mathrm{e} 1000 \mathrm{~m} . \mathrm{s}^{1}\right)^{1}$, whereas significantly higher values were found within the footwall (1300e1700 m.s! ${ }^{1}$; Fig. 8a). Therefore, the fault zone was not a low-velocity zone embedded within a high-velocity protolith, but appeared to be a boundary between two zones of contrasted velocity although the original granitic facies is the same. Another change in velocity was observed near source 15 (Fig. 8 a); however not fault but a set of decametric fractures affected this part of the outcrop, which could potentially account for this change. Dataset 3 also showed an asymmetric distribution of velocity (Fig. 8b). However, the highest variation was located at the minor fault instead of the major fault. This effect was

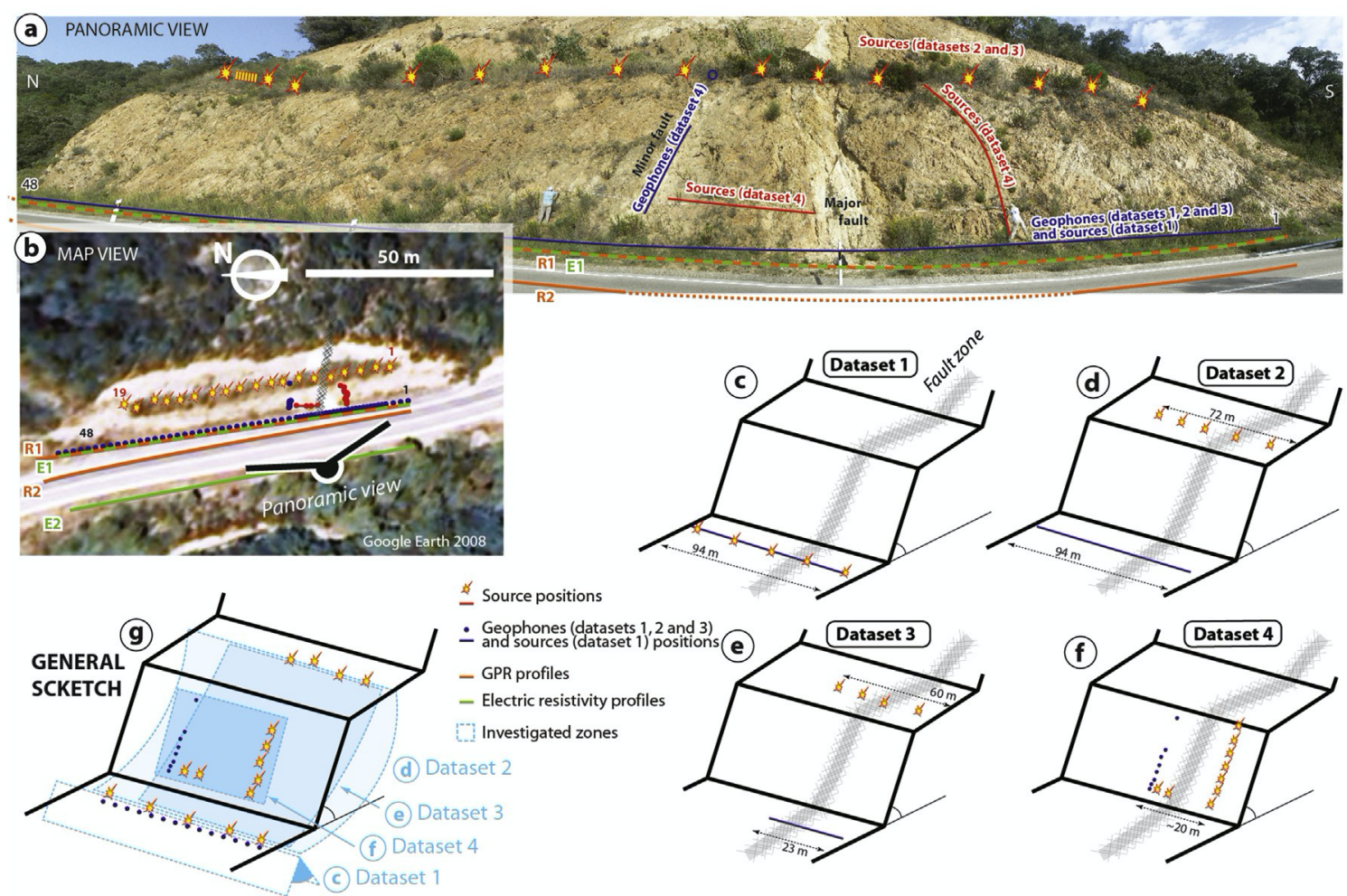

Fig. 7. Panoramic (a) and map (b) views of the Terra Negra site showing the position of the geophysical equipment and faults identified from the outcrop. Inserts (c), (d), (e) and (f) conceptually outline various setups of seismic acquisition; the rock mass investigated with each of the sub-datasets is summarised in (g).

enhanced when restricting the tomographic inversion to short rays (the distance along the profile between the source and receivers did not exceed $7 \mathrm{~m}$ ), as represented in Fig. 8b. No obvious fault-related zoning was revealed from Dataset 4 (Fig. 8c).

This series of observations therefore revealed a scaledependence of the compartmentalisation of the velocity field. Small-scale seismic experiments involved better resolution and short-ray paths, offering a shallow penetration that was more sensitive to the partitioning related to the minor fault (Datasets 3 and 4 ; Fig. $7 \mathrm{~g})$. In contrast, deeper penetration was required to sample the velocity anomaly related to the major fault, as the minor fault strikes almost parallel to the 
outcrop (Datasets 2 and 4; Fig. 7g). The asymmetry of the velocity distribution around fault zones was therefore sampled with various degrees of penetration into the granite, to be related to a general increase of the velocity with penetration.

The highest fracture density was found within the southern block of the major fault zone (Fig. 3e), where low velocities were also found (Fig. 8a and b). However, the block lying between the major and minor faults exhibited a rather low fracture density, as well as low seismic wave velocity (Fig. $3 \mathrm{c}$ and Fig. $8 \mathrm{~b}$ and c). Thin section analysis showed that the primary phases were significantly weathered, with chlorite replacing biotite, for instance (Fig. 3). This showed that not only fracturing but also alteration of the minerals can account for variations of seismic wave velocity.

Considering non-outcropping formations, the along-profile tomography carried out at the bottom of the cliff (Dataset 1) presented two low-velocity anomalies at the location of both the major and minor faults (Fig. 8d). Thus, at this level, no asymmetry of the velocity profile was found about the fault zones, which exhibited velocity values $20 \mathrm{e} 40 \%$ less than that of the fault blocks. Similarly to the Canyet site, neither end of the profile could be interpreted with confidence.

\subsection{Electrical resistivity}

Two low-resistivity anomalies were detected after inversion of the Wenner data, at the locations where the two faults are intersected by the profile (Fig. 8e). As higher water saturation is typically associated with clayey formations in the vadose zone, the fault core material identified at the outcrop could explain the higher conductivity observed locally.

\subsection{GPR}

The fault zones were characterised by a rapid and strong attenuation of the electromagnetic waves, whereas signals could be observed elsewhere all along the profile until at least $60 \mathrm{~ns}$ (Fig. 8f). This suggested the presence of wet clay in the faults. Two signals with an apparent southward dip were found on the radar profile acquired at the bottom of the cliff (Fig. 8f). Reflector 1 emerged at the location of the major fault zone. The actual dip value of this reflector could be approximated after Yilmaz (1987), as follows:

azsin! 1 sin aapp" $\cos \mathrm{q}$

where $q$ was the difference between the dip direction of the reflector and the profile. $a_{a p p}$ was the apparent dip given by $a_{a p p}{ }^{1 / 4}$ sin! $!^{1} ! 2^{\underline{v t}} d "$ where $V$ represented the velocity of the electromagnetic waves, $t$ the two-way propagation time and $d$ the shortest distance from GPR to the reflector. Using a velocity of $1.10^{8} \mathrm{~m} . \mathrm{s}^{1}{ }^{1}$ typical for altered granite (Tillard, 1994), a corrected dip value of $41 \#$ was 


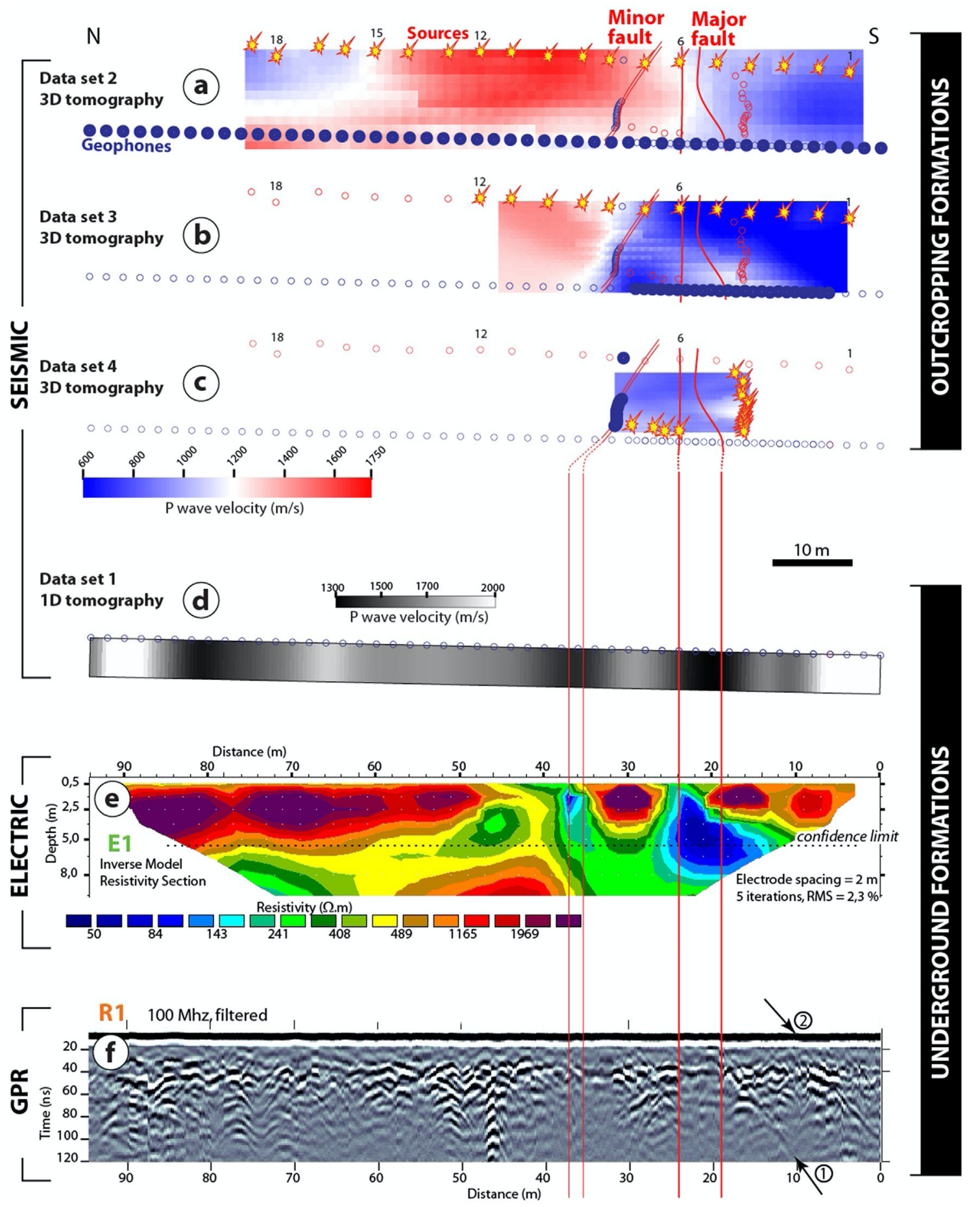

Fig. 8. Results of geophysical surveys carried out at the Terra Negra outcrop. Similarly to the Canyet site (Fig. 5), geophysical properties at depth exhibit symmetric distributions with respect to the fault zones. At higher levels, fault blocks present contrasted properties. 

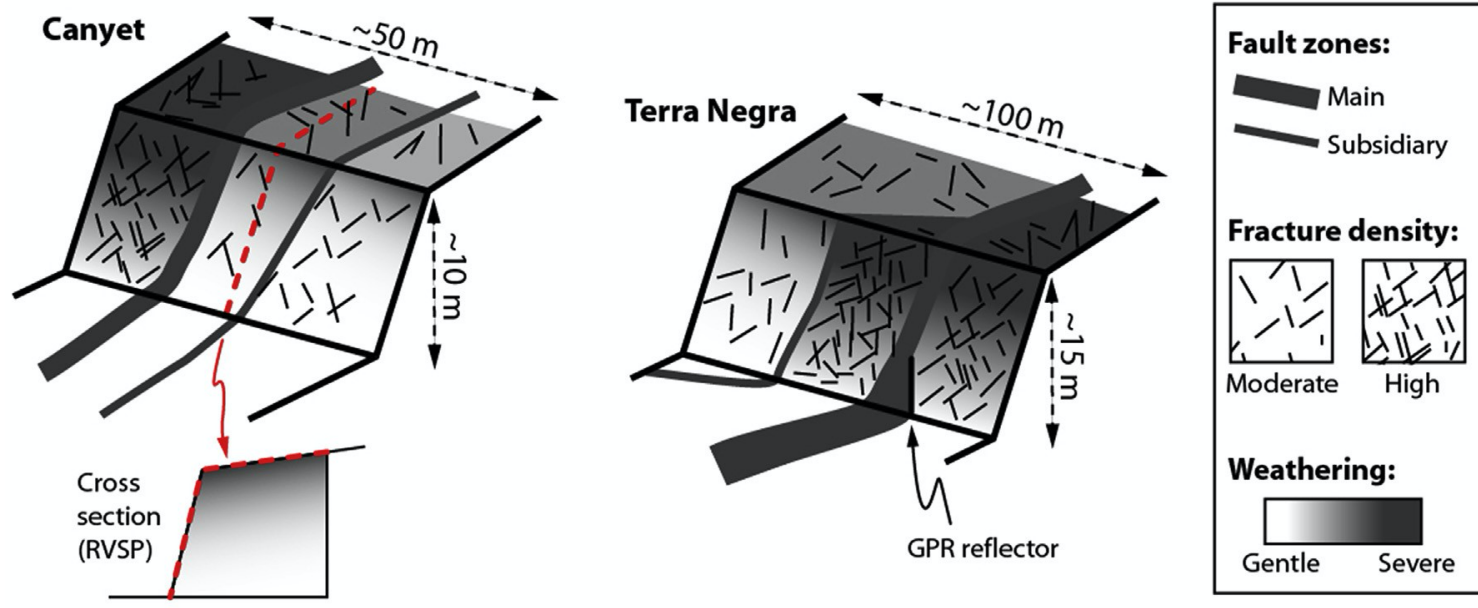

Fig. 9. Summary of the observations of the two case studies, illustrating the simplified spatial distribution of the weathering on each outcrop and the fracture density. Weathering is mostly found at the level of the outcrop, behind the exposed surface. Our data show that very little sign of weathering is found at greater depth, where the fault zones create the only anomalies detected (seismic attenuation, lower P-wave velocity, lower electric resistivity, electromagnetic-waves reflectivity).

found. This did not correspond to the main dip value of the fault zone, but was likely to denote a reflection off a minor structure identified at the outcrop with an orientation of $\mathrm{N} 100$ !E 50 !S, which separated the protolith in the hanging wall from the damage zone in its footwall (southern contour in Fig. 3 ). Reflector 2 could be interpreted as a minor structure as well. However, such a feature has not been observed at the outcrop. Apart from features 1 and 2 , no shallow dipping reflection was detected.

6. Discussion

6.1. General signature of weathering on P-wave seismic velocity

A major observation is the very low P-wave velocity measured at the two sites, Canyet and Terra Negra, as well as at two other sites in the area (La Ermita San Grau and La Cala Salionç, see Place (2010)). 
The velocity values measured from tomographic inversions, ranging from 200 to $5000 \mathrm{~m} . \mathrm{s}^{11}$, reflect various degrees of alteration of the granite, including saprolite and soil. These values are in agreement with velocities as low as $1100 \mathrm{~m} . \mathrm{s}^{11}$ found in severely altered crystalline rocks (Vijaya Raghava et al., 1977 ; Rao Naik et al., 1980; Radzevicius and Pavlis, 1999; Zou and Wu, 2001; Fonseca et al., 2006) and velocities of a few hundred metres per second have been measured in saprolite (Radzevicius and Pavlis, 1999; Fonseca et al., 2006). P-wave velocity variation, covering this whole range, has been clearly measured at Canyet by RVSP, exhibiting the natural alteration front from a shallow soil level to almost fresh granite at around $8 \mathrm{e} 10 \mathrm{~m}$ depth (Fig. $6 \mathrm{~b}$ ). The $10 \mathrm{~m}$ vertical extent of this alteration front is consistent with the decametric to pluri-decametric scale of similar formations reported by Dewandel et al. (2006), Lee and de Freitas (1990), Radzevicius and Pavlis (1999) and Rao Naik et al. (1980).

The fact that the rocks are brought to a free surface allows the stresses to be significantly decreased, and the cracks to open, in addition to damage induced by excavation techniques. The extent of such Excavation Disturbed Zones (EDZ) may vary between less than $1 \mathrm{~m}$ (Alheid et al., 1999; Zou and Wu, 2001), to several metres within the formation (Maxwell and Young,1995; Alheid et al.,1999; Zou and Wu, 2001; Giese et al., 2005) and depends on various factors such as the excavation method, the intrinsic rock properties, the stress state, the time elapsed since the excavation, the free surface geometry, etc. (Alheid et al., 1999). Our results in Canyet show an extent of about $4 \mathrm{~m}$ for an increase of $4500 \mathrm{~m} . s !^{1}$, corresponding to an overall gradient of about $1125 \mathrm{~s} !^{1}$, in agreement with previous studies.

\subsection{Refinement of the weathered halo model}

Common features are observed at the two sites investigated (Fig. 9):

" In the upper parts of the volumes investigated (where forma-tions outcrop), the velocity is relatively homogenous within each block bounded by fault, as seen from the profiles parallel to the cliffs. Major fault zones appear to limit zones exhibiting contrasting P-wave velocities, resulting in strongly asymmetric velocity distributions with respect to the faults. Minor faults play an important role in delimiting the velocity field as well, with low or high-velocity anomalies concentrated between these faults and the major fault, as clearly illustrated in Terra Negra and Canyet, respectively (Fig. 9).

" In the underground formations, low-velocity anomalies, as wellas low-resistivity anomalies, are observed at the fault core location. Unlike in the outcropping formations, the geophysical properties exhibit a significantly more symmetrical pattern around major and minor fault zones, denoting similar properties within their blocks (Fig. 9).

This series of observations allows the model for alteration halo and damage around fault zones developed in granitoids to be refined. Dewandel et al. (2006) and Wyns et al. (2004) produced a conceptual model where the alteration deepens in the vicinity of major structures, with alteration fronts developing irrespective to smaller scale structures such as secondary faults and fractures. Based on this model, Fig. 10 illustrates the control of the geometry of alteration fronts by secondary structures, as evidenced in our study (Fig. 9). In this figure, no significant sub-horizontal structures are represented. Even though such fissured horizons have been described in earlier studies (e.g. Wyns et al., 2004; Guiheneuf et al.,! 2014), the visual inspection analysis of the outcrops studied here (Figs. 2 and 3) and the geophysical data (especially GPR profiles) show no evidence of their occurrence. The development of a fissured zone is therefore not systematic, which is why it has not been represented in our model (Fig. 10).

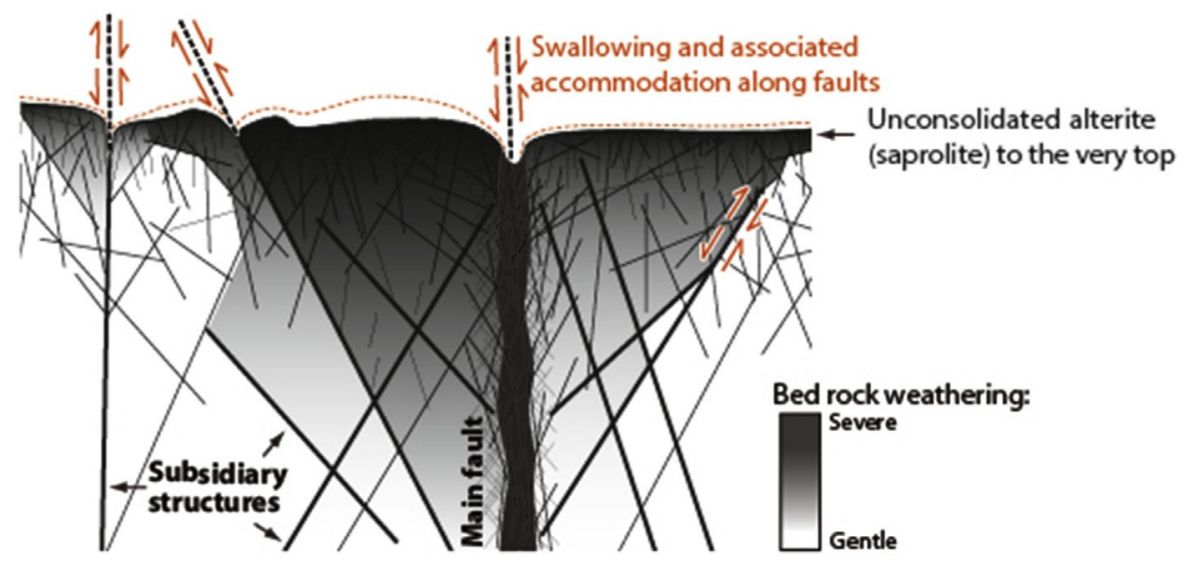

Fig. 10. Conceptual model of weathered basement rocks in the vicinity of faults (modified after Wyns et al. (2004)). Faults delimit blocks affected by varied fracture patterns inherited from deformat processes at greater depth; hydraulic conditions may also be specific to each block due to the low permeability materials in the fault zones. Variations in volume due to the alteration of prim phases, as well as repeated swelling of clay minerals (e.g. in response to changes in hydrological condition), may result in the alteration of the matrix and the formation of new fractures specific to each block, in addition to the reactivation of faults.

6.3. Processes related to the structural control of weathering

In this section, we discuss several causes that may result in the observed strong spatial discrepancy of weathering.

First, it is known that damage and alteration occurring at great depths are not necessarily symmetric with respect to fault cores. This has been observed in deep active systems (Kelly et al., 2013), and outcrop analyses show that the asymmetry persists through exhumation (Berg and Skar, 2005; Mitchell et al., 2011). Aside from differences of rock types on both sides of the fault, several factors may intervene and account for such asymmetry: for example, the interplay between fault propagation and development of the damage zone (Kim et al., 2004; Fossen, 2010), irregularities on the fault trace (Gabrielsen et al., 1998; Aarland and Skjerven, 1998) and differences in the stress conditions from one block to another (Mandl, 2000; Knott et al.,1996). In our field examples, geophysical data acquired at the bottom of the cliffs (and therefore sampling relatively deep formations) show a rather symmetrical distribution of the geophysical properties with respect to the fault cores (below 10 and $20 \mathrm{~m}$ for Canyet and Terra Negra, respectively). This could be interpreted in a first approach as a symmetrical damage and alteration. 
However, the asymmetric distribution of quartz and carbonate veins at Canyet reflects asymmetric damage around the fault core, acquired when the system was active and developing at a greater depth. In either outcrop, the fracture patterns do not show predominant sets of fractures that are sub-parallel to the excavation or erosion surfaces (Fig. $2 \mathrm{~d}$ and e; Fig. $3 \mathrm{~g}$ and h); therefore unloading due to excavation is more likely to reactivate preexisting structures than to help new cracks develop. However, the seismic velocity field at the two sites does not correlate with the fracture density. We therefore interpret the seismic velocities to reflect not only the presence of fractures, but also the degree of matrix weathering, as evidenced by the thin sections (clay formation and development of porosity; Figs. 2 and 3).

Second, in a near-surface environment, the minor faults and fractures can govern the drainage of meteoric water within fault blocks. The structural network within each block allows various amounts of fluids to be stored and to circulate (e.g. Roques et al., 2014). In addition, in our cases studies, millimetric to centimetric thick clay zones were found within the cores of these subsidiary faults, which can act as barriers to groundwater flow. Interplay between topography and fault zone orientation may form retention zones or zones where fluid can be drained more easily. All these factors could contribute to the chemical alteration to be compartmentalised by the structural network.

Moreover, physical damage is closely related to chemical alteration (e.g. Røyne et al., 2008): primary minerals subject to alteration may change into minerals of larger volume, resulting in failure within minerals or at grain boundaries and a potential increase in permeability (e.g. Fletcher et al., 2006). In granitoids, biotite is the mineral most likely to expand when altered (Farmer and Wilson, 1970; Isherwood and Street, 1976; Buss et al., 2008; Rodbell et al., 2012). Samples taken from an Australian weathering profile have shown that, locally, the volume increase related to the alteration of biotite can reach $40 \%$ (Banfield and Eggleton, 1988). The analysis of our samples shows that primary phases are altered, for example biotite is replaced by chlorite (see section: Geological Setting); this is likely to have occurred at high temperature and pressure. Smectite and kaolinite were also found (see Appendix), which can both result from the weathering of granitoids, namely from feldspars (Folk, 1947; Banfield and Eggleton, 1988; Kawano and Tomita, 1994; Taboada and Garcia, 1999; Dethier and Bove, 2011). Smectite is known to be a swelling mineral: its lattice parameters change upon wetting, resulting in volume changes. Even though kaolinite is not a swelling clay, laboratory experiments have shown that aggregates of this clay may expand due to geometrical redistribution of the minerals when water is absorbed onto the surface (Rutter, 1983). As expansion and shrinking cycles of clay assemblages are likely to occur due to seasonal infill and drainage of faults blocks, physical damage may also occur, not only as a consequence of the irreversible alteration of primary minerals, but also over a much shorter term of cycles (seasonal) (see dotted lines and arrows in Fig. 10). The density, extent and orientation of the structures formed during weathering, as well as the matrix properties, are therefore expected to be specific to each block, in response to the boundary condition (faults delimiting the block and in some cases a free surface) and to the inherited fracture pattern. This specific character may even be enhanced by the presence of faults bordering each block, as a slight amount of slip related to differential volume changes can be accommodated. Consequently, the drainage capacities through these fracture networks will differ from one block to another, which will in turn be reflected onto the matrix properties. In addition to rather short-term seasonal cycles, the exhumation rate may also influence the development of the weathering profile. The model proposed by Wyns et al. (2004) (including smooth boundaries and a sub-horizontally fractured horizon) is derived from case studies located in Brittany, France, where the exhumation rate is much lower than that of the crystalline basement of the Catalan Costal Ranges. Not only the stress field, as suggested by Owen et al. (2007), but also the time scale of the exhumation may dictate the development of weathering. We therefore believe that the fracture distribution, drainage, matrix properties, stress field and time scale of exhumation are key parameters that interplay during weathering.

\subsection{Consequences for aquifers, reservoirs and mining applications}

As the distribution of the geophysical properties is compartmentalised, accurate estimations of the amount of fluids and their ability to circulate in the weathering halo would require investigation of all fault blocks. In some cases, one can even expect the highest grades of weathering to occur in blocks that are not necessarily next to the main fault zones. Even though the relationships between petrophysical (e.g. porosity and permeability) and geophysical properties have not been discussed in this paper, smooth porosity and permeability gradients as a function of depth and distance from the fault seem inappropriate, as our geophysical data show that the severity of weathering does not evolve smoothly with distance from the fault or the erosional surface. Therefore, the smoothly narrowing model does not systematically apply to any case study and has to be significantly revised. The structural control of weathering has relevance for shallow applications for water recovery in HRA (as studied for instance by Courtois et al. (2010), Foster (2012) and Leray et al. (2013)). The refined model described in our paper also has incidence on the exploitation of hydrocarbon, geothermal and mining resources as, in some places, paleo-weathered top basement rocks are found at great depth below a sedimentary cover. In such case, the detection and mapping of alteration halos using geophysical methods may be difficult because of the potential asymmetry of the halos, the various sizes of blocks whose geophysical properties exhibit wide ranges of magnitude, and the jagged nature of the contours of the haloes, which may diffract elastic or electromagnetic waves. In any case, the weathered top basement rock cannot be considered as a simple layer due to the strong lateral heterogeneities and the non-systematic occurrence of sub-horizontal structures revealed in this study.

\section{Conclusion}

Multi-method geophysical characterisation of weathered fault zones in granites have showed that the geophysical properties of the fault materials exhibit complex spatial distributions in which faults and fractures play the role of boundaries to the severity of the weathering. This compartmentalisation is not only governed by major faults, but also by minor structures such as subsidiary faults. The basic symmetrical and smoothly narrowing alteration halo model should be revised, and take into account a potentially asymmetric pattern with sharp contrasts of geophysical properties located on secondary structures. In general, the weathered domain of a crystalline basement cannot be considered as a simple layer due to the strong and complex lateral heterogeneities and the nonsystematic occurrence of structures that are sub-parallel to the erosion surfaces.

It is thought that the compartmentalisation of the weathering profile results from an interplay between the structural networks inherited from deeper and former processes and weatheringrelated factors such as groundwater drainage, chemical alteration and deformation, which may be specific to each fault block. Thus, each fault block may undergo complex weathering processes with a high degree of independence relative to neighbouring blocks.

Further geological characterisation of the outcrops, including fracture pattern quantification, porosity and permeability measurements, microstructural and Xray diffraction analysis within each fault block, are required to better understand the complex relationships between fluids, matrices and fractures, as well as chemical alteration and physical damage involved in weathering processes. Such an approach would allow the influence of host rock mineralogy, structural inheritance and hydrothermal alteration as well as erosion (involving climate and geodynamic settings), on the location and severity of weathering to be investigated. 


\section{Acknowledgements}

We are grateful to ADEME (France) and ElfER (Germany) for funding this study. We would also like to thank Julien Guillemoteau (Universite de Strasbourg) and Hagen Dekert (IGEM) for their help! in carrying out the "espectacular" field work that provided the datasets used in this study. We are also grateful to Karl-Josef Sandmeier (Sandmeier Scientific Software) for developing the 3D tomography module of Reflexw for the purpose of this study and to Fabienne Huber and Melanie Denecker (Universit! e de Strasbourg)! for helping with the X-ray diffraction analyses. Dan Faulkner, Alan Boyle, Andreas Rietbrock (University of Liverpool) and Tom Blenkinsop (Cardiff University) are thanked for constructive discussions and feedback and Kay Lancaster (University of Liverpool) is acknowledged for improvement of the figures. Finally, we are grateful to Clement Roques and Zoe Shipton for their constructive! reviews of the manuscript.

Figure 10 is partly made of material reproduced with permission from the Societ! e G! eologique de France.!

Appendix

Fault zone materials were sampled at both sites for mineralogical analysis (Figs. 2 and 3). Samples A and D were collected within the core of Canyet and Terra Negra faults, respectively. At Terra Negra, the damage zone (sample B) and the material either side of the contact of the core and damage zone (sample C) were sampled.

Fine fractions (<2 micron) were separated and oriented for analysis through X-ray diffraction, after standard treatment including air drying, solvation with hydrazine or ethylene glycol, and heating (490 !C for 4 h) (Moore and Reynolds, 1997).

Although the peak at $3.33 \AA$ may be related to residual quartz, illite is abundant in all samples with clear peaks at 5 and $10 \AA$ (Fig. A1). Smectite was distinguishable from illite by its peak at $15 \AA$ after drying, and translated up to $17 \AA$ after saturation with ethylene glycol vapour. Kaolinite was revealed in samples $B$ and $D$ by peaks at 7.15 and $3.57 \AA$ after air drying, the former being unaffected by ethylene glycolation, but not surviving heat treatment (Fig. A1). The presence of kaolinite in samples $A$ and $C$ can only be suspected due to slight bulges in the curves. 

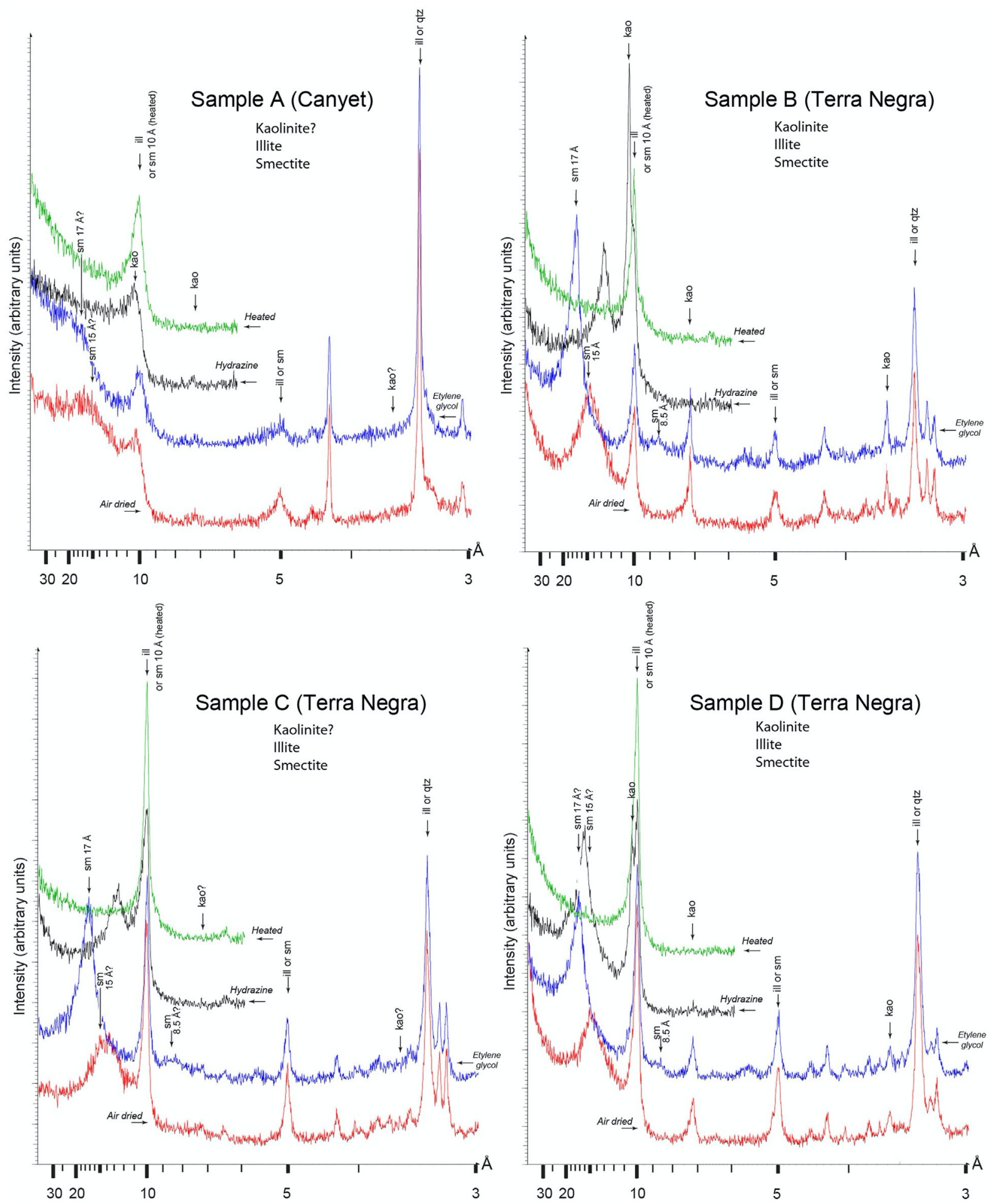

Fig. A1. Clay mineral XRD patterns of $<2$ micron fractions following air drying, ethylene glycol, hydrazine and heat ( 490 !C for $4 \mathrm{~h}$ ) treatments. Illite and smectite are present in all samples, whereas kaolinite is clearly identified in samples B and D only.

References

Aarland, R.K., Skjerven, J., 1998. Fault and fracture characteristics of major fault zone in the northern North Sea: analyses of 3D seismic and oriented cores in the Brage Field (Block 31/4). In: Coward, M.P., Daltaban, T.S., Johnson, H. (Eds.), Structural Geology in Reservoir Characterization, 127, pp. 209e229.

Acworth, R.I., 1987. The development of crystalline basement aquifers in a tropical environment. Quat. J. Eng. Geol. 20, 265e272.

Aydin, A., 2000. Fractures, faults, and hydrocarbon entrapment, migration and flow. Mar. Petroleum Geol. 17, 797e814.

Alheid, H.J., Knecht, M., Ludeling, R., 1998. Seismic measurements for the investigation of the excavation damaged zone in the vicinity of underground openings. Geotechnik 21 (3), $248 \mathrm{e} 251$.

Alheid, H.J., Knecht, M., Boisson, J.-Y., Homand-Etienne, F., Pepa, S., 1999. Comparison of in-situ hydraulic and seismic measurements in the excavation damaged zone of underground drifts. In: Vouille, G., Berest, P. (Eds.), 9th International Society for Rock Mechanics, 2, pp. 1263e1266. August 25-28 1999, Paris.

Aquilina, L., De Dreuzy, J.-R., Bour, O., Davy, P., 2004. Porosity and fluid velocities in the upper continental crust ( 2 to 4 km) inferred from injection tests at the Soultz-sous-Forets geothermal site. Geochimica Cosmochimica Acta 68 (11),^ 2405e2415. 
Arche, A., Díez, J.B., Lopez-G! omez, J., 2007. Identi! fication of the early Permian (Autunian) in the subsurface of the Ebro Basin, NE Spain, and its paleogeographic consequences. J. Iber. Geol. 33 (1), $125 \mathrm{e} 133$.

Arthaud, F., Matte, P., 1975. Les decrochements tardi-hercyniens du sud-ouest de! l'Europe. Geom! etrie et essai de reconstitution des conditions de la d! eformation.! Tectonophysics 25, $139 \mathrm{e} 171$.

Banfield, J.F., Eggleton, R.A., 1988. Transmission electron microscope study of biotite weathering. Clays Clay Minerals 36 (1), 47 e60.

Bartrina, M.T., Cabrera, L., Jurado, M.J., Guimera, J., Roca, E., 1992. Evolution of the" central Catalan margin of the Valencia trough (western Mediterranean). Tectonophysics 203 (1e4), 219e247.

Bense, V.F., Gleeson, T., Loveless, S.E., Bour, O., Scibek, J., 2013. Fault zone hydrogeology. Earth-Science Rev. 127, 171e192.

Berg, S.S., Skar, T., 2005. Controls on damage zone asymmetry of a normal fault zone: outcrop analyses of a segment of the Moab fault, SE Utah. J. Struct. Geol. 27 (10), 1803 1822.

Biscaldi, R.,1968. Problemes hydrog" eologiques des r! egions d'af! fleurement de roches eruptives! et metamorphiques! sous climat tropical. Bull. du Bureau des Recherches Geologiques Mini! eres, Deuxi" eme s" erie, Sect. III 2, 7! e22.

Bisdom, E.B.A., Stoops, G., Delvigne, J., Curmi, P., Altemuller, H.J., 1982. Micromorphology of weathering biotite and its secondary products. Pedologie 32 (2), $225 \mathrm{e} 252$.

Bixel, F., 1987. Le volcanisme stephano-permien des Pyr! en! ees. P! etrographie, min-! eralogie, g! eochimie. Cuad. Geol. Ib! erica 11, 41 ! e55.

Boiron, M.-C., Cathelineau, M., Richard, A., 2010. Fluid flows and metal deposition near basement/cover unconformity: lessons and analogies from PbeZneFeBa systems for the understanding of Proterozoic U deposits. Geofluids 10 (1e2), 270e292.

Bourgeois, O., Ford, M., Diraison, M., Le Carlier de Veslud, C., Gerbault, M., Pik, R., Ruby, N., Bonnet, S., 2007. Separation of rifting and lithospheric folding signatures in the NW-Alpine foreland. Int. J. Earth Sci. 96, 1003e1031.

Brace, W.F., 1984. Permeability of crystalline rocks: new in situ measurements. J. Geophys. Res. 89, 4327e4330.

Buss, H.L., Sak, P.B., Webb, S.M., Brantley, S.L., 2008. Weathering of the Rio Blanco quartz diorite, luquillo Mountains, Puerto Rico: coupling oxidation, dissolution, and fracturing. Geochimica Cosmochimica Acta $72(18), 4488 \mathrm{e} 4507$.

Caine, J.S., Tomusiak, S.R.A., 2003. Brittle structures and their role in controlling porosity and permeability in a complex Precambrian crystalline-rock aquifer system in the Colorado rocky mountain Front Range. GSA Bull. 115 (11), 1410e1424.

Caine, J.S., Evans, J.P., Forster, C.B., 1996. Fault zone architecture and permeability structure. Geology 24 (11), 1025e1028.

Carmichael, 1989. In: Carmichael (Ed.), Practical Handbook of Physical Properties of Rocks and Minerals, ISBN 0-8493-3703-8, p. 741.

Carvalho, J., Lisboa, J.V., Torres, L., Mendes-Victor, L.A., 2000. Rock mass evaluation using in-situ velocity and attenuation measurements. Eur. J. Environ. Eng. Geophys. 5 (1), 15 e31.

Carvalho, J., Pinto, C., Lisboa, J.V., Sardinha, R., Catrapona, A., Borges, J., Tlemçani, M., 2010. Assessing the Degree of Fracturing and Weathered Layer Thickness Using Seismic and GPR Data. 72nd EAGE Conference \& Exhibition incorporating SPE. EUROPEC 2010, Barcelona, p. 5. Spain (14-17 june).

Chandra, S., Nagaiah, E., Reddy, D.V., Ananda Rao, V., Ahmed, S., 2013. Exploring deep potential aquifer in water scarce crystalline rocks. J. Earth Syst. Sci. 121 (6), 1455e1468.

Chandra, S., Dewandel, B., Dutta, S., Ahmed, S., 2010. Geophysical model of geological discontinuities in a granitic aquifer: analyzing small scale variability of electrical resistivity for groundwater occurrences. J. Appl. Geophys. 71 (4), 137e148.

Childs, C., Manzocchi, T., Walsh, J.J., Bonson, C.G., Nicol, A., Schopfer, M.P., 2009.€ A geometric model of fault zone and fault rock thickness variations. J. Struct. Geol. 31 (2), 117 127.

Chilton, P.J., Smith-Carington, A.K., July 1984. Characteristics of the weathered basement aquifer in Malawi in relation to rural water supplies. In: Walling, D.E., Foster, S.S.D., Wurzel, P. (Eds.), Challenges in African Hydrology and Water Resources 157 (Proceedings of the Harare Symposium, 144. IAHS Publications, pp. 57e72.

Courtois, N., Lachassagne, P., Wyns, R., Blanchin, R., Bougaïre, F.D., Som! e, S.,! Tapsoba, A., 2010. Large-scale mapping of hard-rock aquifer. Ground Water 48 (2), 269 e283.

Cuong, T.X., Warren, J.K., 2009. Bach Ho field, a fractured granitic basement reservoir, Cuu Long basin, Offshore SE Vietnam: a "Buried-Hill" play. J. Petroleum Geol. 32 (2), 129 e156.

Dethier, D.P., Bove, D.J., 2011. Mineralogic and Geochemical changes from alteration of granitic rocks, Boulder Creek Catchment, Colorado. Vadose Zone J. 10 (3), 858 e866.

Dewandel, B., Lachassagne, P., Zaidi, F.K., Chandra, S., 2011. A conceptual hydrodynamic model of a geological discontinuity in hard rock aquifers: example of a quartz reef in granitic terrain in South India. J. Hydrology 405 (3e4), 474e487. Dewandel, B., Lachassagne, P., Wyns, R., Marechal, J.C., Krishnamurthy, N.S., 2006.! A generalized 3-D geological and hydrogeological conceptual model of granite aquifers controlled by single or multiphase weathering. J. Hydrology 330 (1e2), $260 \mathrm{e} 284$.

Doblas, M., Lopez-Ruiz, J., Oyarzun, R., Mahecha, V., Moya, Y.S., Hoyos, M., Cebria, J.M., Capote, R., Enrile, J.H., Lillo, J., Lunar, R., Ramos, A., Sope! na, A., 1994. Extensional tectonics in the central Iberian Peninsula during the Variscan to Alpine transition. Tectonophysics 238 (1e4), 95e116.

Dontsov, V.V., Lukin, A.E., 2006. Endogenous factors of the formation of oil fields in the crystalline basement of the Cuu Long Basin, south Vietnam shelf. Dokl. Earth Sci. 407 (1), $188 \mathrm{e} 191$.

Dujardin, J.-R., Bano, M., 2013. Topographic migration of GPR data: examples from Chad and Mongolia. Comptes Rendus Geosci. $345,73 e 80$.

Durand, V., Deffontaines, B., Leonardi, V., Gu! erin, R., Wyns, R., de Marsily, G.,! Bonjour, J.-L., 2006. A multi- disciplinary approach to determine the structural geometry of hard-rock aquifers. Application to the Plancoet migmatitic aquifer (NE Brittany, W France). Bull. la Societ! e G! eologique Fr. 177, 227! e237.

Edel, J.B., Schulmann, K., Lexa, O., Diraison, M., Geraud, Y., 2015. Permian clockwise! rotations of the Ebro and Corso-Sardinian blocks during IberianeArmorican oroclinal bending: preliminary paleomagnetic data from the Catalan Coastal Range (NE Spain). Tectonophysics 657, 172e186.

Farmer, V.C., Wilson, M.J., 1970. Experimental conversion of biotite to hydrobiotite. Nature 226 (5248), 841e842.

Faulkner, D.R., Mitchell, T.M., Jensen, E., Cembrano, J., 2011. Scaling of fault damage zones with displacement and the implications for fault growth processes. J. Geophys. Res. Solid Earth 116 (B5), B05403.

Fletcher, R.C., Buss, H.L., Brantley, S.L., 2006. A spheroidal weathering model coupling porewater chemistry to soil thicknesses during steady-state denudation. Earth Planet. Sci. Lett. 244, 444e457.

Folk, R.L., 1947. The alteration of feldspar and its products as studied in the laboratory. Am. J. Sci. 245 (6), 388e394.

Folk, R.L., Patton, E.B., 1982. Buttressed expansion of granite and development of grus in central Texas. Z. für Geomorphol. 26, 17 e32.

Fonseca, A.V.D., Carvalho, J., Ferreira, C., Santos, J.A., Almeida, F., Pereira, E., Feliciano, J., Grade, J., Oliveira, A., 2006. Characterization of a profile of residual soil from granite combining geological, geophysical and mechanical testing techniques. Geotechnical Geol. Eng. 24 (5), 1307e1348.

Fossen, H., 2010. Structural Geology. Cambridge Univsersity Press, p. 463.

Foster, S., 2012. Hard-rock aquifers in tropical regions: using science to inform development and management policy. Hydrogeol. J. 20 (4), 659 e672.

Gabrielsen, R.H., Aarland, R.-K., Alsaker, E., 1998. Identification and spatial distribution of fractures in porous, siliclastic sediments. In: Coward, M.P., Daltaban, T.S., Johnson, H. (Eds.), Structural Geology in Reservoir Characterization. Geological Society, pp. 49e64. London, Special Publications.

Genter, A., Traineau, H., 1996. Analysis of macroscopic fractures in granite in the HDR geothermal well EPS-1, Soultz-sous-Forets, France. J. Volcanol. Geotherm.

Res. $72(1 \mathrm{e} 2), 121 \mathrm{e} 141$.

Giese, R., Klose, C., Borm, G., 2005. In situ seismic investigations of fault zones in the Leventina Gneiss Complex of the Swiss Central Alps. In: Harvey, P.K., Brewer, T.S., Pezard, P.A., Petrov, V.A. (Eds.), Petrophysical Properties of Crystalline Rocks, 240, pp. 15e24. Geological Society, London, Special Publications.

Guiheneuf,! N., Boisson, A., Bour, O., Dewandel, B., Perrin, J., Dausse, A., Viossanges, M., Chandra, S., Ahmed, S., Marechal, J.C., 2014. Groundwater! flows in weathered crystalline rocks: Impact of piezometric variations and depthdependent fracture connectivity. J. Hydrology 511, 320e334.

Gustafson, G., Krasn!ý, J., 1994. Crystalline rock aquifers: their occurrence, use and importance. Hydrogeology J. 2 (2), 64 e75.

Gutmanis, J.C., 2009. Basement Reservoirs - a Review of Their Geological and Production Characteristics. International Petroleum Technology Conference, Doha, p. 7. Qatar(7-9 December).

Gutmanis, J.C., Batchelor, T., Cotton, L., Baker, J., 2012. Hydrocarbon Production from Fractured Basement Formations. Public report, p. 43. version 10. http://www. geoscience.co.uk/downloads.html.

Hayles, J.G., Everitt, R.A., Woodcock, D.R., 1999. A 15 kHz cross-hole seismic survey across a fracture at the AECL Underground Research Laboratory. Can. J. Earth Sci. 36 (9), 1517 1532.

Hill, S.M., 1996. The differential weathering of granitic rocks in Victoria, Australia. J. Aust. Geol. Geophys. 16 (3), 271e276.

Isherwood, D., Street, A., 1976. Biotite-induced grussification of the Boulder Creek granodiorite, Boulder County, Colorado. Geol. Soc. Am. Bull. 87 (3), $366 e 370$.

Jamtveit, B., Putnis, C.V., Malthe-Sørenssen, A., 2009. Reaction induced fracturing during replacement processes. Contrib. Mineral. Petrol. 157, 127e133.

Jamtveit, B., Kobchenko, M., Austrheim, H., Malthe-Sørenssen, A., Røyne, A., Svensen, H., 2011. Porosity evolution and crystallization-driven fragmentation during weathering of andesite. J. Geophys. Res. Solid Earth 116, B12204. http:// dx.doi.org/10.1029/2011JB008649.

Jamtlid, A., Magnusson, K.-Å., Olsson, O., Stenberg, L., 1984. Electrical borehole€ measurements for the mapping of fracture zones in cristalline rock. Geoexploration $22,203 e 216$.

Jeanne, P., Guglielmi, Y., Cappa, F., 2012. Multiscale seismic signature of a small fault zone in a carbonate reservoir: relationships between VP imaging, fault zone architecture and cohesion. Tectonophysics $554 \mathrm{e} 557(0), 185 \mathrm{e} 201$

Kawano, M., Tomita, K., 1994. Growth of smectite from leached layer during experimental alteration of albite. Clays Clay Minerals 42 (1), 7e17.

Kelly, C.M., Rietbrock, A., Faulkner, D.R., Nadeau, R.M., 2013. Temporal changes in attenuation associated with the 2004 M6.0 Parkfield earthquake. J. Geophys. Res. Solid Earth 118 (2), 630 e645.

Kim, Y.-S., Peacock, D.C.P., Sanderson, D.J., 2004. Fault damage zones. J. Struct. Geol. 26 (3), 503e517. 
Kirkpatrick, J.D., Shipton, Z.K., Evans, J.P., Micklethwaite, S., Lim, S.J., McKillop, P., 2008. Strike-slip fault terminations at seismogenic depths; the structure and kinematics of the Glacier Lakes fault, Sierra Nevada, U.S.A. J. Geophys. Res. 113 (B4), B04304. http://dx.doi.org/10.1029/2007JB005311.

Knott, S.D., Beach, A., Brockbank, P.J., Brown, J.L., McCallum, J.E., Welbon, A.I., 1996. Spatial and mechanical controls on normal fault populations. J. Struct. Geol. 18 (2e3), 359 e372.

Lachassagne, P., Wyns, R., Dewandel, B., 2011. The fracture permeability of hard rock aquifers is due neither to tectonics, nor to unloading, but to weathering processes. Terra Nova 23 (3), $145 \mathrm{e} 161$.

Le Borgne, T., Bour, O., Paillet, F.L., Caudal, J.-P., 2006. Assessment of preferential flow path connectivity and hydraulic properties at single-borehole and crossborehole scale in a fractured aquifer. J. Hydrology 328,347 e359.

Lee, S.G., de Freitas, M.H., 1990. Seismic Refraction Surveys for Predicting the Intensity and Depth of Weathering and Fracturing in Granitic Masses. Geol. Soc., Lond., Eng. Geol. Spec. Publ. 6, 241 256. Leray, S., de Dreuzy, J.-R., Bour, O., Bresciani, E., 2013. Numerical modeling of the productivity of vertical to shallowly dipping fractured zones in crystalline rocks. J. Hydrology 481,64 e75.

Lewis, C.J., Verges, J., Marzo, M., 2000. High mountains in a zone of extended crust:" Insights into the Neogene-Quaternary topographic development of northeastern Iberia. Tectonics 19 (1), 86 e102. Luthi, S.M., 2005. Fractured reservoir analysis using modern geophysical well techniques: application to basement reservoirs in Vietnam. Geol. Soc., Lond., Spec. Pub. 240 (1), 95 e106.

McFarlane, M.J., 1992. Groundwater movement and water chemistry associated with weathering profiles of the african surface in Malawi. In: Wright, E.P., Burgess, W.G. (Eds.), Hydrogeology of Crystalline Basement Aquifers in Africa, 66, pp. 101e129. Geological Society, London, Special Publications.

Mandl, G., 2000. Faulting in Brittle Rocks. An Introduction to the Mechanics of Tectonic Faults. Springer, Berlin, p. 434.

Manning, D.A.C., Younger, P.L., Smith, F.W., Jones, J.M., Dufton, D.J., Diskin, S., 2007. A deep geothermal exploration well at Eastgate, Weardale, UK: a novel exploration concept for low-enthalpy resources. J. Geol. Soc. 164, 371e382. London.

Martínez-Poza, A.I., Druguet, E., Castano, L.M., Carreras, J., 2014. Dyke intrusion into a preexisting joint network: the Aiguablava lamprophyre dyke swarm (Catalan CoastalRanges),. Tectonophysics 630, $75 \mathrm{e} 90$.

Martínez, F.J., Reche, J., Iriondo, A., 2008. UePb Shrimp-RG zircon ages of Variscan igneous rocks from the Guilleries massif (NE Iberia pre-Mesozoic basement). Geological implications. Comptes. Rendus. Geosciences 340, 223e232.

Mauffret, A., Durand de Grossouvre, B., Tadeu Dos Reis, A., Gorini, C., Nercessian, A., 2001. Structural geometry in the eastern Pyrenees and western Gulf of Lion (Western Mediterranean). J. Struct. Geol. 23 (11), 1701e1726.

Maxwell, S.C., Young, R.P., 1995. A controlled in-situ investigation of the relationship between stress, velocity and induced seismicity. Geophys. Res. Lett. 22 (9), 1049 e1052.

Mitchell, T.M., Ben-Zion, Y., Shimamoto, T., 2011. Pulverized fault rocks and damage asymmetry along the Arima-Takatsuki Tectonic Line, Japan. Earth Planet. Sci. Lett. 308 (3e4), 284e297.

Moore, D.M., Reynolds, R.C., 1997. X-ray Diffraction and the Identification and Analysis of Clay Minerals. Oxford University Press, p. 378.

Neuman, S.P., 2005. Trends, prospects and challenges in quantifying flow and transport through fractured rocks. Hydrogeology J. 13, 124e147.

Neves, M., Morales, N., 2007. Well productivity controlling factors in crystalline terrains of southeastern Brazil. Hydrogeology J. 15, 471e482.

Ngoc, S.L., 2007. An integrated geology and reservoir engineering approach for modelling and history matching of a Vietnamese fractured granite basement reservoir. In: SPE Europec/EAGE Annual Conference, p. 10. London, UK(11-14

June).

Nishimoto, S., Yoshida, H., 2010. Hydrothermal alteration of deep fractured granite: effects of dissolution and precipitation. Lithos 115, $153 \mathrm{e} 162$.

Olesen, O., Dehls, J.F., Ebbing, J., Henriksen, H., Kihle, O., Lundin, E., 2007. Aeromagnetic mapping of deep-weathered fracture zones in the Oslo Region e a new tool for improved planning of tunnels. Nor. J. Geol. 87, $253 e 267$.

Olona, J., Pulgar, J.A., Fernandez-Viejo," G., Lopez-Fern" andez," C., Gonzalez-" Cortina, J.M., 2010. Weathering variations in a granitic massif and related geotechnical properties through seismic and electrical resistivity methods. Near Surf. Geophys. 8, 585e599.

Owen, R., Maziti, A., Dahlin, T., 2007. The relationship between regional stress field, fracture orientation and depth of weathering and implications for groundwater prospecting in crystalline rocks. Hydrogeology J. 15, 1231e1238.

Petford, N., McCaffrey, K., 2003. Hydrocarbons in Crystalline Rocks: an Introduction. Geol. Soc., Lond., Spec. Pub. 214 (1). NP- normal.

Place, J., 2010. Caracterisation des chemins de circulations de" fluides dans le reseau" poreux d'un batholite granitique. In: Application au site geothermique de" Soultz-sous-Forets, p. 364. Ph.D. of the University of Strasbourg^

Place, J., Sausse, J., Marthelot, J.-M., Diraison, M., Geraud, Y., Naville, C., 2011. 3D" mapping of permeable structures affecting a deep granite basement using isotropic 3C VSP data. Geophys. J. Int. $186(1), 245 \mathrm{e} 263$.

Radzevicius, S.J., Pavlis, G.L., 1999. High-frequency reflections in granite? Delineation of the weathering front in granodiorite at Pinon flat, California. Geophysics 64 (6), 1828 e1835.

Rao Naik, S., Kumar, B., Raghava, G.N., V, M.S., 1980. The correlation refraction methods as applied to weathered zone studies in a granite terrain. Geophys. Prospect. 28 (1), $18 \mathrm{e} 29$.

Riebe, C.S., Kirchner, J.W., Granger, D.E., Finkel, R.C., 2001. Strong tectonic and weak climatic control of long-term chemical weathering rates. Geology 29 (6), 511 e514.

Rodbell, D.T., Frey, H.M., Manon, M.R.F., Smith, J.A., McTurk, N.A., 2012. Development of unusual rock weathering features in the Cordillera Blanca, Peru. Quat. Res. 77 (1), 149e158.

Roques, C., Bour, O., Aquilina, L., Dewandel, B., Leray, S., Schroetter, J.M., Longuevergne, L., Le Borgne, T., Hochreutener, R., Labasque, T., Lavenant, N., Vergnaud-Ayraud, V., Mougin, B., 2014.

Hydrological behavior of a deep subvertical fault in crystalline basement and relationships with surrounding reservoirs. J. Hydrology 509,42 e54.

Røyne, A., Jamtveit, B., Mathiesen, J., Malthe-Sørenssen, A., 2008. Controls on rock weathering rates by reaction-induced hierarchical fracturing. Earth Planet. Sci. Lett. 275,364 e369.

Rutter, E.H., 1983. Pressure solution in nature, theory and experiment. J. Geol. Soc. 140 (5), 725 e 740.

Salas, R., Casas, A., 1993. Mesozoic extensional tectonics, stratigraphy and crustal evolution during the Alpine cycle of the eastern Iberian basin. Tectonophysics 228 (1e2), $33 \mathrm{e} 55$.

Salisbury, M., Harvey, C., Matthew, L., 2003. Hardrock seismic exploration: mature technologies adapted to new exploration targets. In: Eaton, D., Milkereit, B., Salisbury, M. (Eds.), Part I: Physical Rock Properties and Geophysical Logging: SEG Book, pp. 9e41.

Schutter, S.R., 2003. Occurrences of hydrocarbons in and around igneous rocks. Geol. Soc., Lond., Spec. Pub. 214 (1), 35 e68.

Seranne, M., 1999. The gulf of lion continental margin (NW Mediterranean) revis-" ited by IBS: an overview. Geol. Soc., Lond., Spec. Pub. 156, 15 e36.

Sicar, A., 2004. Hydrocarbon production from fractured basement formations. Curr. Sci. 87 (2), 147e151.

Smith, S.A.F., Bistacchi, A., Mitchell, T.M., Mittempergher, S., Di Toro, G., 2013. The structure of an exhumed intraplate seismogenic fault in crystalline basement. Tectonophysics 599 (0), 29 e44.

Soden, A.M., Shipton, Z.K., Lunn, R.J., Pytharouli, S.I., Kirkpatrick, J.D., do Nascimento, A.F., Bezerra, F., 2014. Brittle structures focused on subtle crustal heterogeneities: implications for flow in

fractured rocks. J. Geol. Soc. 171, 509e524. http://dx.doi.org/10.1144/jgs2013-051.

Sole, J., Cosca, M., Sharp, Z., Enrique, P., 2002." $\quad{ }^{40} \mathrm{Ar} /{ }^{39} \mathrm{Ar}$ Geochronology and stable isotope geochemistry of Late-Hercynian intrusions from north-eastern Iberia with implications for argon loss

in K-feldspar. Int. J. Earth Sci. 91, 865e881.

Stampfli, G.M., Borel, G.D., Marchant, R., Mosar, J., 2002. Western alps geological constraints on western Tethyan reconstructions. J. Virtual Explor. 7, 75 e104.

Taboada, T., Garcia, C., 1999. Smectite formation produced by weathering in a coarse granite saprolite in Galicia (NW Spain). CATENA 35 (2e4), 281 e290.

Tassone, A., Roca, E., Munoz, J.A., Cabrera, L., Canals, M., 1994. Evoluci $\quad$ on del sector" septentrional del margen catalan durante el Cenozoico. Acta Geol. Hisp. $29 "$ (2e4), 3e37.

Taylor, R., Howard, K., 2000. A tectono-geomorphic model of the hydrogeology of deeply weathered crystalline rock: evidence from Uganda. Hydrogeology J. 8 (3), $279 \mathrm{e} 294$.

Tieh, T.T., Ledger, E.B., Rowe, M.W., 1980. Release of uranium from granitic rocks during in situ weathering and initial erosion (central Texas). Chem. Geol. $29,227$.

Tillard, S., 1994. Radar experiments in isotropic and anisotropic geological formations (granite and schists). Geophys. Prospect. 42 (6), 615 e636.

Verges, J., Fern" andez, M., Martinez, A., 2002. The Pyrenean orogen: pre-, syn-, and\# post-collisional evolution. J. Virtual Explor. 8, 19.

Vijaya Raghava, M., Jawahar, S., Sherbakova, G., V, T., 1977. Ultrasonic profiling investigation on some fresh and weathered granites of Hyderabad, India. Geophys. Prospect. 25 (4), 768 e779.

Virgili, C., Paquet, H., Millot, G., 1974. Alteration du soubassement de la couverture permo-triasique en Espagne. Bull. du. Groupe français des. Argiles XXVI, 277 e285.

Wenner, F., 1915. A method of measuring earth resistivity. Bull. Bureau Stand. 12 (3), 469e478. Report No. 258.

Wyns, R., Quesnel, F., Simon-Coinon, R., Guillocheau, F., Lacquement, F., 2003. Major weathering in France related to lithospheric deformation. Geologie de la Fr. 1," 79e87.

Wyns, R., Baltassat, J.-M., Lachassagne, P., Legchenko, A., Vairon, J., Mathieu, F., 2004. Application of proton magnetic resonance soundings to groundwater reserve mapping in weathered basement rocks (Brittany, France). Bull. Soc. Geol. Fr. 175 (1), 21 e34.

Yilmaz, O., 1987. Seismic data processing. In: Society of Exploration Geophysicists, p. 2027.

Younger, P.L., Manning, D.A.C., 2010. Hyper-permeable granite: lessons from testpumping in the Eastgate Geothermal Borehole, Weardale. UK. Q. J. Eng. Geol. Hydrogeology 43, 5e10. http://dx.doi.org/10.1144/1470-9236/08-085.

Ziegler, P.A., 1992. European Cenozoic rift system. Tectonophysics 208 (1e3), 91e111.

Zou, D.H., Wu, Y.K., 2001. Investigation of blast-induced fracture in rock mass using reversed vertical seismic profiling. J. Appl. Geophys. 48 (3), $153 \mathrm{e} 162$. 